\title{
Nature and Origin of Spectacular Marine Miocene Shell Beds of Northeastern Patagonia (Argentina): Paleoecological and Bathymetric Significance
}

\author{
CLAUDIA J . DEL RÍO \\ Museo Argentino de Ciencias Naturales "Bernardino Rivadavia”, Sección Paleoinvertebrados, Angel Gallardo 470 \\ (1405), Buenos Aires, Argentina \\ SERGIO A. MARTÍNEZ \\ Instituto Nacional de Geología y Paleontología, Facultad deCiendias, I guá 4225 (11400), Montevideo, U ruguay \\ ROBERTO A. SCASSO \\ Facul tad deCiencias Exactas y Naturales, Ciudad Universitaria, Pabel lón 2, (1428), Buenos Aires, Argentina
}

PALAIOS, 2001, V. 16, p. 3-25

Biofacies and taphonomic analysis has allowed for the re construction of the paleoenvironmental history of accumuIation of a series of spectacular mollusk-dominated shelconcentrations from thePuerto Madryn Formation and the benthic assemblages that inhabited the Miocene sea in northern Patagonia, Argentina. An upward-shallowing from open mid-shelf to more restricted shorefaceforeshore environments has been recognized. Transgressive, Maximum Highstand and Regressive phases are recognized based on the integrated approach of assemblages and lithofacies arrangement. Eleven mollusk-dominated fossil assemblages weredefined and grouped into Associations A, B, and C. Transgressive and Maximum Highstand phases preserve thre main shell beds that record an upwards change from dynamic to complete bypassing conditions. These were deposited in tidal current-dominated mid-and inner-sheff environments and belong within Assodation A. The top bedding surface records the maximum depth attained by the sea. The RegressivePhaseis characterized by threeupward-deepening cycles comprised of foreshoreshorefacesandbar deposits containing Association C. Sandbars are capped by environmentally condensed shell-beds of Association $B$ and record deposition from theshoreface (wave breaking zone) to mid-sheff environments, all abovestormwavebase

Based on these fossil assemblages, seven benthic life associations can be identified. The deepest ones inhabited the mid-to-inner shelf and were represented by suspensionfeeders from gravel-substrata swept by strong tidal currents and by suspension-feeders from lower energy firm bottoms. Lower shoreface sandy bottoms, close to fairweather wave baseand affected by weak tidal currents, wereinhabited by epifaunal suspension-feeders, whereas sandy bottoms close to the fai rweather wave-breaking zone were characterized by semi-infaunal deposit feeders and suspension feeders. Theshallowest living assemblages inhabited intertidal and foreshore settings and were represented by soft-bottom infaunal suspension feeders, as well as by firm bottom, vagile carni vorous and suspension-feeding epi fauna.

\section{INTRODUCTION}

One of the most conspicuous features of themarine Miocene deposits of northeastern Patagonia are the thick beds composed of accumulations of exceptionally well-pre served molluskan shells. These shell beds comprise $55 \%$ of the total thickness of the sequence reported herein, and their detailed pal eoecologic and taphonomic analyses provide new insights on Miocene sea-level dynamics (T-R cy(le), and environmental conditions.

The species composition of each assemblage is described, along with taphonomic insights and their paleoecological significance. Additionally, a refined set of paleoenvironmental interpretations is provided, based on cluster analysis of the faunal data and the spatial distribution of assemblages. Exceptionally well-preserved and varied faunas have allowed for extensive autoecological investigation. Bathymetric interpretations from comparison of Miocene taxa with their congeneric Recent taxa are consistent with the environmental conditions derived from classical facies analysis and from comparison with well studied, modern sedimentary environments (e.g., German Bight). Finally, consideration of discontinuities, internal stratigraphy, and context of the major shell beds provided the opportunity to reconstruct sedimentary history in the context of relative sea-level changes.

\section{STRATIGRAPHY AND PALEOGEOGRAPHY}

A large area of Argentina was flooded during Miocene times by a shallow sea known in the literatureas the " $\mathrm{En}$ trerriense" or "Paranense" sea (see del Río and Martínez, 1998a; del Río, 2000 and bibliography herein; Fig.1A). A southern branch of this "Entrerriense" sea occupied península Valdés and the area surrounding the city of Puerto Madryn (Chubut Province) in northeastern Patagonia (Fig.1B). In this region, the "Entrerriense" deposits are part of the Puerto Madryn Formation (Haller, 1978), which overlies the Late Oligocene-Early Miocene? " $\mathrm{Pa}$ tagoniense" horizons and comprises $150 \mathrm{~m}$ of heterolithic and cross-bedded sandstones, muddy sandstones, and sandy mudstones interbedded with white tuffs and distinctiveshell beds (Fig. 2).

0883-1351/01/0016-0003/\$3.00 


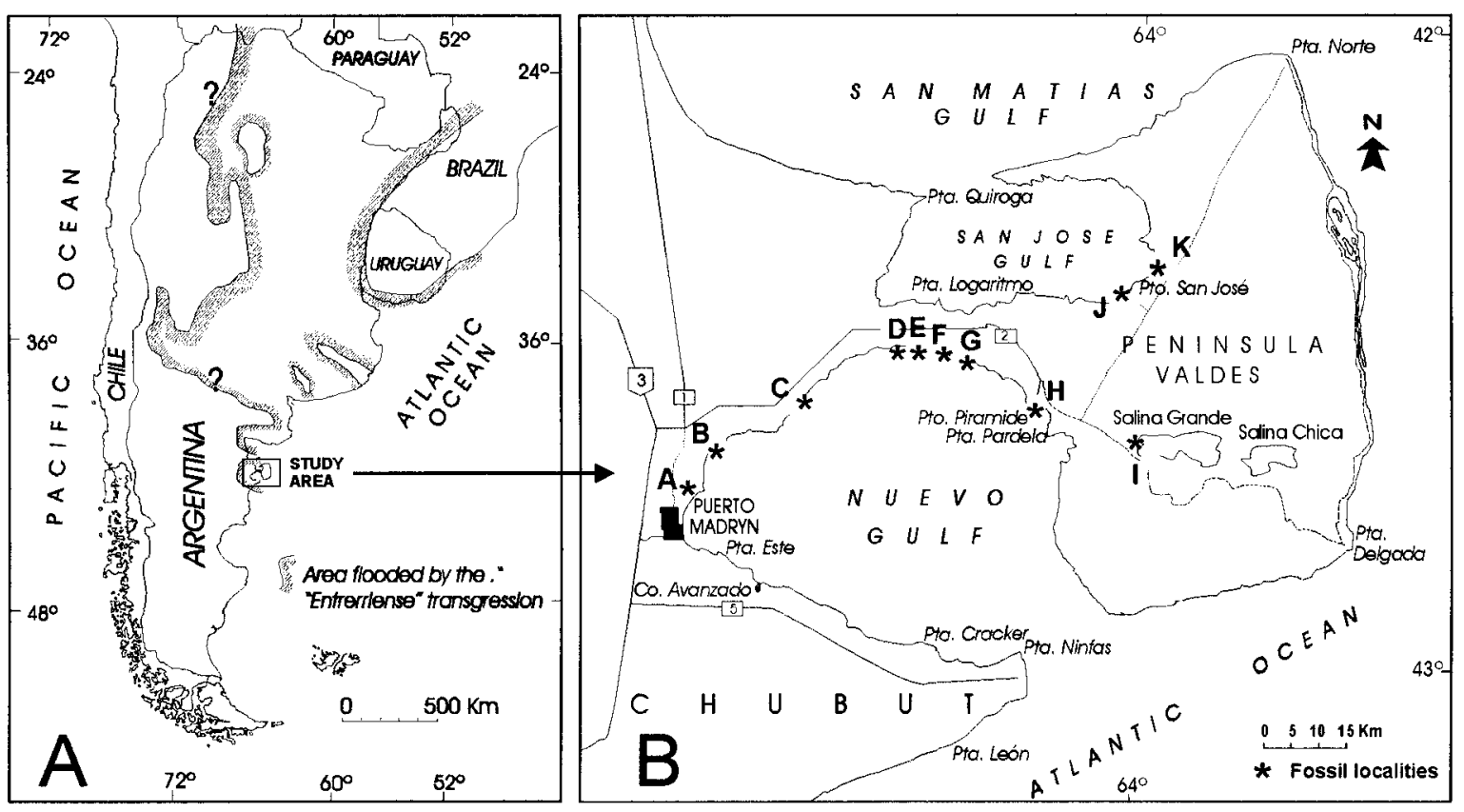

FIGURE 1-Argentina and area of the present investigation. (A) Paleogeography of Argentina during the Miocene. (B) Location of fossiliferous sections of Miocene coastal outcrops. A-Bajo de Madryn, B-El Doradillo, C-Cerro Prismático, D-Las Charas, E-Eje tentativo W, F-Eje Tentativo Ob, G-Eje Tentativo E, H-Puerto Pirámide's area, I-Salina Grande, J-San José, and K—Lote 39.

The age of "Entrerriense" deposits in Argentina has been discussed largely since the last century. On the basis of molluskan faunas, these deposits have been assigned to the late Middle Miocene (del Río, 1988, 1989, 1992, seediscusion of age herein) and to the early Late Miocene based on ${ }^{87} \mathrm{Sr} /{ }^{86} \mathrm{Sr}$ evidence (Scasso et al. 1999a).

Reconstruction of "Entrerriense" pal eogeography (Scasso and del Río, 1987) indicates that deposition of the "Entrerriense" beds took place in a gulf or a wide bay that extended west from the main oceanic water body. As with most marine Tertiary deposits of Patagonia, the distribution of the "E ntrerriense" indicates the westward penetration of a sea that was open to the east, to the Atlantic Ocean. The sea did not extend beyond a N-S line $25 \mathrm{~km}$ west the city of Puerto Madryn. To the north, the paleocoast can be traced along the Sierra Grande highs and their eastern extension (currently below sea level). The south coast can betraced al ong therío Chubut area, where no "Entrerriense" deposits are recorded, and its continuation to the east on the present shelf. The existence of a paleohigh in the south is inferred; the Middle-Late Miocene of the río Chubut area is characterized by continental deposits with many internal discontinuities, and facies and paleocurrent patterns within the "Entrerriense" basin point to provenance and sediment dispersion from the south and southwest.

Based on the vertical recurrence of faunal assemblages (this paper) and lithofacies arrangement (Scasso and del Río,1987), the lowermost fossiliferous 75 meters of the Puerto Madryn Formation can be subdivided intoa Transgressive Phase, a Maximum Highstand Phase, and a Regressive Phase (Figs. 2-3). The Maximum Highstand Phase refers to deposits that accumulated when the sea level was at its maximum, before the regression took place. Thus, this term is not equivalent to highstand sys- tem tract as it is normally used in sequence stratigraphy, (i.e., for maximum highstand and regressive phases).

The combined Transgressive and Maximum Highstand Phases are 30 meters thick, and arewell exposed along the northern coastline of the Golfo Nuevo in theE je Tentativo area (Fig.3) The overlying Regressive Phase of the sequence is 45 meters thick, and the best exposures extend from the Puerto Pirámide area eastwards to Península Valdés. Westwards from Cerro Prismático, where the shallowest deposition is recorded (Fig.4), it is not possible to subdivide the "Entrerriense" deposits, but the lowermost transgressive horizons are recognizable at EI Doradillo and Cerro Prismático. The Regressive Phase represents the gradual regression of the "Entrerriense" sea, a product of relatively high sedimentation rates of volcaniclastic materials sourced from basic and mesosilicic volcanic eruptions in the extra-Andean and in the Cordillera de los Andes, respectively (Scasso and del Río, 1987). As a result of sediment aggradation, the entire system prograded and depocenters shifted to the east and northeast during deposition. The Peninsula Valdes region probably became emergent about 9 Ma ago (Scasso et al., 1999a).

\section{DESCRIPTION OF FOSSIL ASSEMBLAGES}

The "Entrerriense" fauna consists mostly of mollusks, which were studied by del Río (1992, 1994), del Río and Martínez (1998b) and Martínez et al. (1998), who described 29 gastropods and 42 bivalves species. These are accompanied by subsidiary bryozoans, brachiopods, barnacles, crabs, and one species of irregular echinoid. Vertebrate fossils also are fairly common and consist of marine and terrestrial mammal, bird, and fish remains, recovered from the lowermost and uppermost horizons of the sequence (Cione, 1978, 1988; Cione and Tonni, 1981; Coz- 


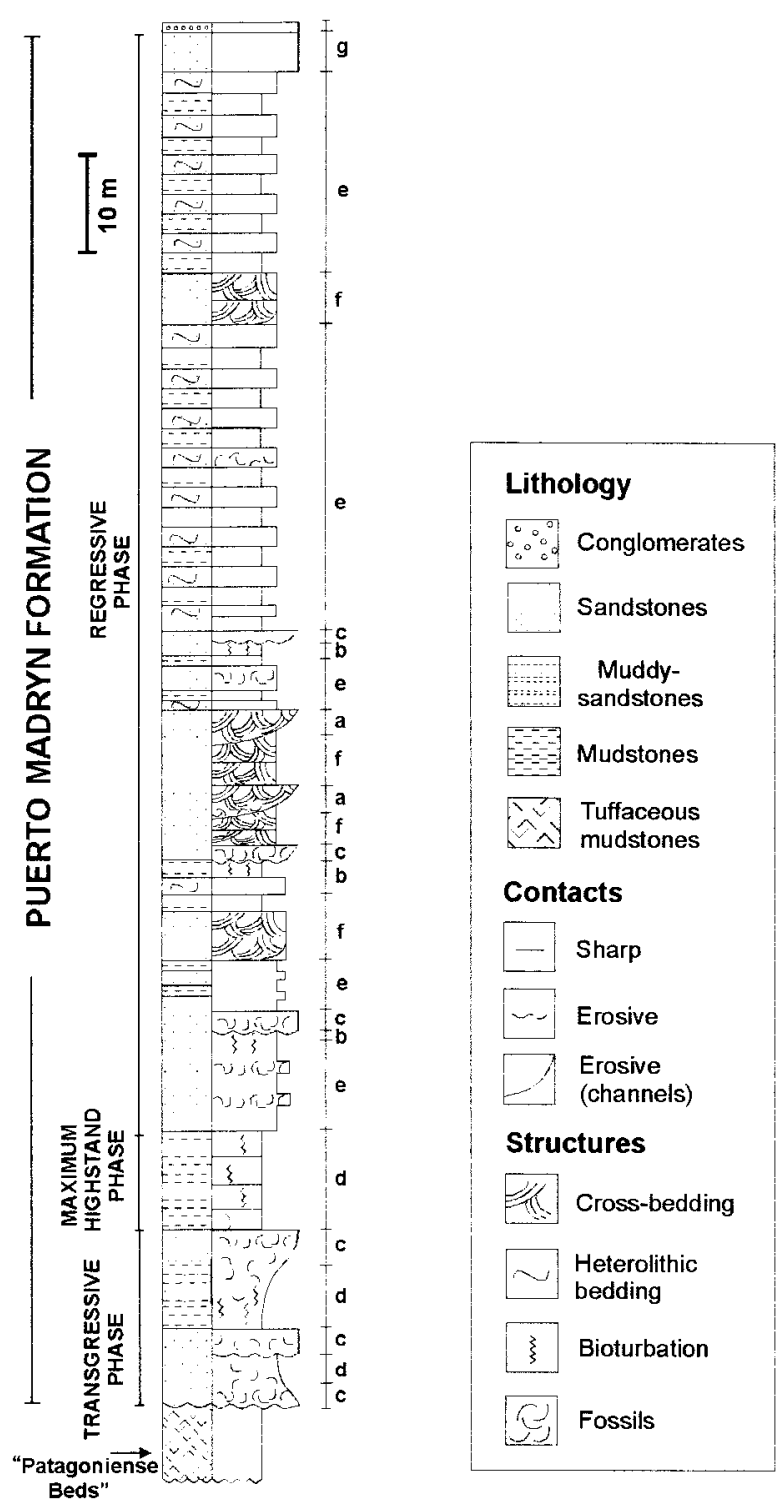

FIGURE 2-Composite stratigraphic column of the Puerto Madryn Formation: Lithofacies coded as in Scasso and del Río (1987): (a) reworked shell beds and conglomeratic sandstones with cross bedding (tidal channels); (b) Fossiliferous shoreface sandbars; (c) Fossiliferous storm-beds from lower shoreface to inner-shelf settings; (d) massive or laminated mudstones (inner mid-shelf); (e) heterolithic beds (shoreface sand tongues and tidal flat) (f) cross-bedded sandstones from megaripples and sand waves (tidal channels and subtidal shoreface bars); (g) paleosols and mudstones (terrestrial and saline marsh environments).

zuol et al., 1993; Riva Rossi, 1996; Dozo et al., 1999). Bivalves are the most diverse and abundantly represented group, with oysters and pectinids the prevalent taxa. Although not abundant, veneroids constitute a diverse group.

Regarding trophic structure (Table 1), the largest group corresponds to suspension feeders, largely dominated by sessile as well as by free-lying epifauna that inhabit firm bottoms, and by semi-infaunal dwellers from gravel substrata. Shallow and deep burrowing infauna typical of soft bottoms are less frequent. Deposit feeders are represented by the lunulate echinoid Monophoraster darwini that usually makes up monospecific assemblages. In specific horizons vagile carni vorous epifauna, mostly characteristic of firm bottoms, also are common.

Both simple and complex shell beds are recognized, following the classification proposed by Kidwell (1986, 1991). Simple beds are single-event concentrations, typically a few centimeters thick, that pinch-out over short distances and may "float" in almost barren intervals with no defined lower and upper contacts. They typically capturecensus or time-averaged fossil assemblages. Complex shell beds, in contrast, are amal gamated, multi-event concentrationsup to $10 \mathrm{~m}$ thick; these are commonly lenticular bodies of large lateral extent, with sharp lower and/or upper contacts, and contain time-averaged, within-habitat, or environmentally condensed fossil assemblages.

Eleven fossil assemblages were recognized from Q-mode cluster analysis based on the relative abundances of spe cies from 166 samples of 50 to 200 specimens each. Samples were recovered from different events that make up 107 shell beds from 15 sections. Appendix 1 summarizes the relative abundance of species and the resulting assemblages that were subsequently assigned to each sample. Cluster analyses (Fig. 5) were done using three similarity indexes (Manhattan, Eucliddean, and Squared distances; Appendix 1). Complete, simple, and UPGMA linkage methods were performed. The resulting dendrograms show minor differences with a largenumber of closely similar shell beds clustering into 11 clearly defined groups. However, a few samples remain separate from the defined groups. These include B21, D7, F4, F5,G4, G7, H11, I3, I7, and $\mathrm{K} 13$, all of which are pavements made up by Glycymerita magna and, hence, were included in Assemblage GROT. Samples A4, A6, A11, J 3, I19, J 8, H4C, and F 16, also do not cluster with any defined groups and, because all are constituted by different species of veneroids, they were considered as bel onging in the $V$ Assemblage. Group D2-D4 links with samples belonging in Assemblage GROT, but field data (see Appendix I) reveals that their composition is closer to Assemblage OCAT.

Assemblages are of low to moderately low diversity and mostly record indigenous, within-habitat concentrations of hardparts. Their stratigraphic distribution is illustrated in Figure 3, and taxonomic composition, taphonomic features of each assemblage, as well as ecological and environmental requirements are summarized in Tables 1 , and 2 and Appendix 1.

\section{Oyster (Os) Assemblage}

This is the most common assemblage and is recovered throughout the Puerto Madryn F ormation. The dominant taxa are the suspension feeders Ostrea patagonica and Ostrea alvarezi, the former often making up monospecific assemblages. According to autoecological comparison with Recent relatives, oysters may live in different substrates due to a high phenotypic plasticity. They can adopt a cemented type of life and constitute biostromes or bioherms on firm bottoms, or be "secondary soft-bottom dwellers" with different morphologic adaptations to environments with high net sedimentation rates (Seilacher, 1984; Chinzei, 1995; Sprechmann et al., 1998). In thestudy area, two ecophenotypes of "secondary soft-bottom dwellers" 

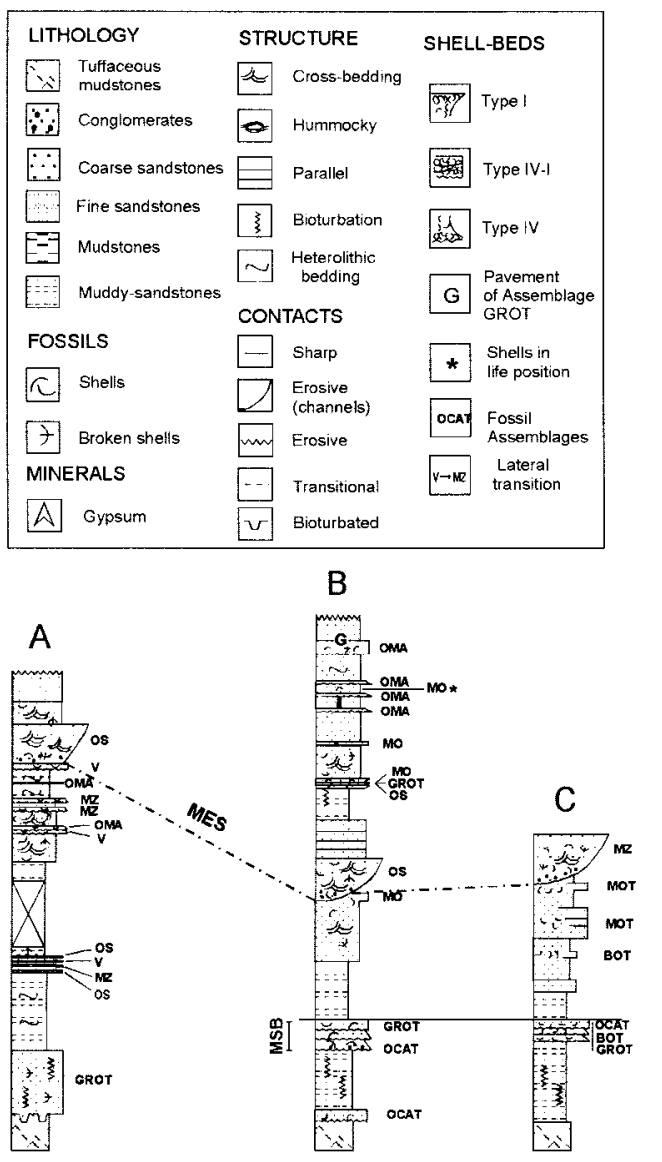

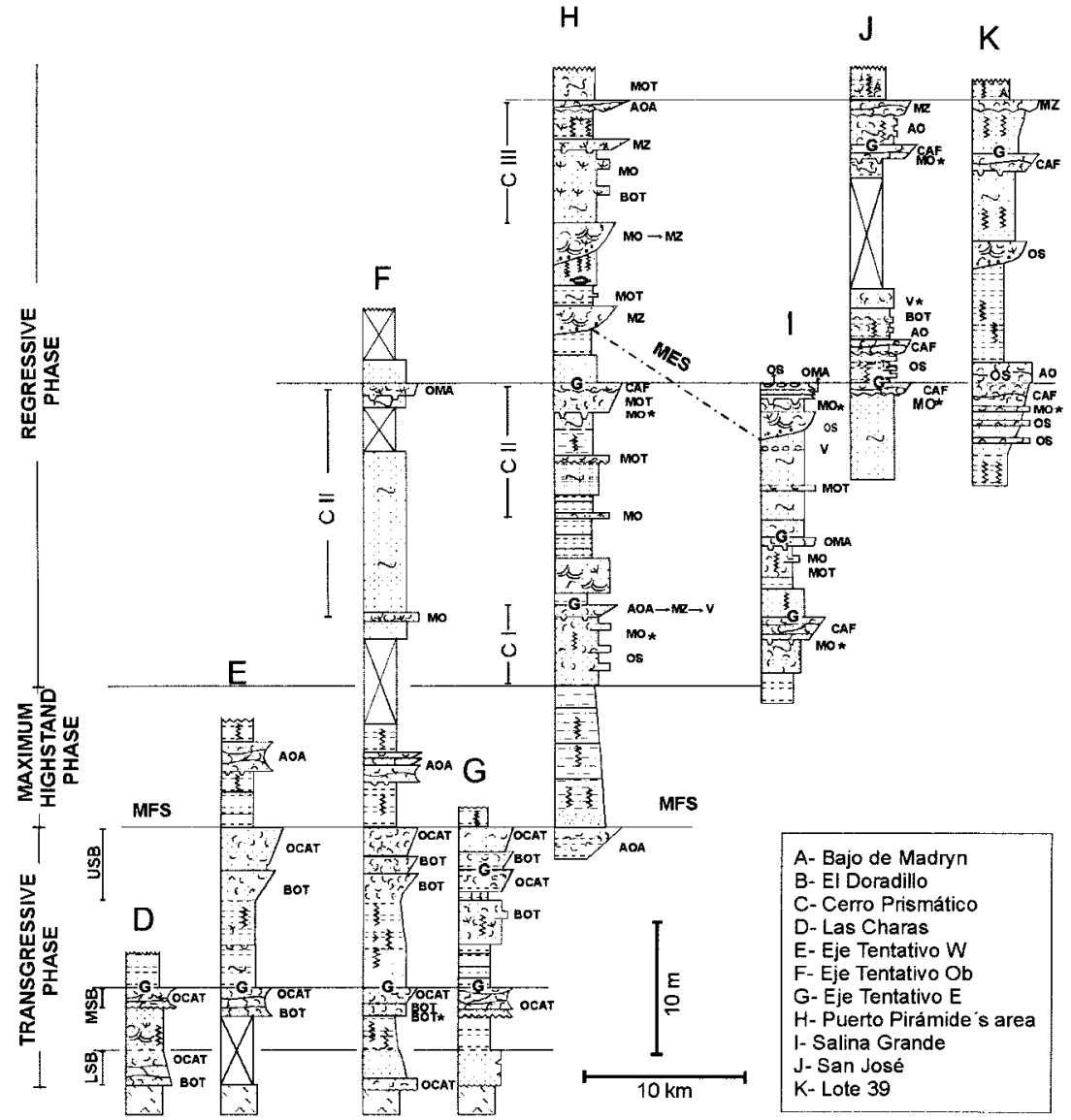

FIGURE 3-Correlation of stratigraphic sections of the Puerto Madryn Formation with occurrences of Assemblages. LSB (Lower shell bed), MSB (Middle shell bed), USB (Upper shell bed); C = sedimentary cycles; MFS = maximum flooding surface; MES = major erosional surfaces from incised valleys to the west, and large channels to the east.

are recognized: bunched forms (O. alvarezi and O. patagonica) and rediner boulder-shaped forms (O. patagonica), both being free lying types that inhabit soft muddy or sandy bottoms. The former consists of nearly vertical bunches of at least three valves cemented to each other, while the latter one has shells that lie on the left convex valve. On the basis of the mentioned antecedents, higher sedimentation rates are inferred for bunched oysters than for freelying ones.

Three taphofacies are recognized (Table 2): (1) census assemblages that may be "floating" in otherwise barren in-

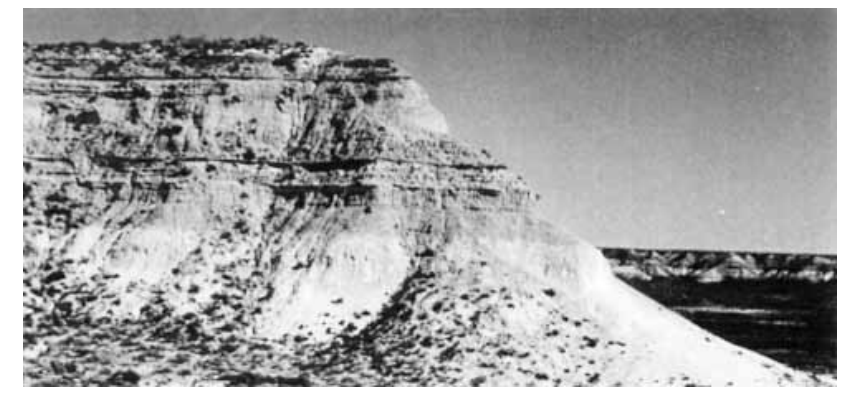

FIGURE 4-The shallowest deposits of the Puerto Madryn Formation (dark strata) overlying the "Patagonian beds" (whitish strata) at Bajo de Madryn. tervals or constitute pavements at the top of other coquinas; (2) thin, single-event and time-averaged accumulations, often lying on erosive bed contacts; and (3) thick, time-averaged multi-event accumulations that constitute channel infillings and, wherein some cases, oysters are accompanied by pectinid, veneroid, gastropod, and echinoid remains.

\section{Glycymerita magna (GROT) Assemblage}

This assemblage is recovered almost exclusively from thick multi-event accumulations in the Transgressive Phase of the sequence and also from thin single-event pavements that cap shell beds throughout the unit (Fig. 6).

The cl osest Recent relative of the dominant taxon of this assemblage (Glycymerita magna) is Glycymeris glycymeris, from the English Channel. It is an opportunistic reophile species (Levinton, 1970) that inhabits shell-gravel substrates strongly swept by tidal currents, at depths ranging from 40 to $100 \mathrm{~m}$. It tolerates high turbulencelevels and is a member of the low-diversity "Boreal Offshore Gravel Association" of Holmes (1966). A living counterpart of Retrotapes ninfasienses is the widespread R. exal bida, a species that also prefers shell-gravel substrates where dense populations are recorded. According to Thomas 
TABLE 1-Relative abundances of taxa within each Fossil Assemblage. D = Dominant ( $>50 \%)$; $A=$ abundant $(25 \%-50 \%) ; C=$ common $(25 \%-5 \%)$; $R=$ rare $(<5 \%)$; AT $=$ attached; $\mathrm{VAG}=$ vagile; $\mathrm{F}$ = free; $\mathrm{EPI}=$ epifauna; INF = infauna; SINF = semi-infaunal.

\begin{tabular}{|c|c|c|c|c|c|c|c|c|c|c|c|c|c|c|c|}
\hline \multirow[b]{2}{*}{ SPECIES } & \multicolumn{12}{|c|}{ Assemblages } & \multirow{2}{*}{$\begin{array}{c}\text { LIFE } \\
\text { HABITAT }\end{array}$} & \multirow{2}{*}{$\begin{array}{c}\text { TROPHIC } \\
\text { GROUP }\end{array}$} & \multirow[b]{2}{*}{ DEPTH RANGE } \\
\hline & GROT & OCAT & BOT & OS & $\mathrm{AO}$ & AOA & CAF & MO & OMA & V & MOT & $M Z$ & & & \\
\hline Bryozoans & $\mathrm{R}$ & $\mathrm{R}$ & D & & & & & & & & & C & AT-EPI & Suspension & INNER-MID-SHELF \\
\hline “Turritella” sp. & C & C & A & & & & & & $\mathrm{R}$ & & $\mathrm{R}$ & $\mathrm{C}$ & VAG-SINF & Omnivorous & SHOREF-MID-SHELF \\
\hline Retrotapes ninfasiensis & A & & & & & & & & & & & & SINF & Suspension & INNER-SHELF \\
\hline Glycymerita magna & $\mathrm{D}$ & & & & & & & & & & & & SINF & Suspension & INNER SHELF \\
\hline Ostrea alvarezi & C & C & C & A & & & C & & & & $\mathrm{D}$ & C & AT-EPI & Suspension & UBIQUITOUS \\
\hline Ostrea patagonica & $\mathrm{C}$ & C & $\mathrm{R}$ & $\mathrm{D}$ & $\mathrm{D}$ & C & C & $\mathrm{D}$ & C & & & $\mathrm{C}$ & AT/F-EPI & Suspension & UBIQUITOUS \\
\hline Chlamys actinodes & & D & & & & & C & & & & & & AT-EPI & Suspension & INNER MID-SHELF \\
\hline Aequipecten paranensis & & A & & & & A & A & & A & & $\mathrm{R}$ & $\mathrm{C}$ & AT-EPI & Suspension & SHOREF-INNER-SHELF \\
\hline Amusium paris & & & & & D & D & A & & & & & & F-SINF & Suspension & SHOREF. \\
\hline Flabellipecten piramidesensi & & & & & & & c & & & & & & F-SINF & Suspension & SHOREF. \\
\hline Chesapecten crassus & & & & & & & C & & & & & & AT-EPI & Suspension & SHOREF \\
\hline Monophoraster darwini & & & & & & & & D & A & & $\mathrm{R}$ & $\mathrm{C}$ & VAG-SINF & Deposit & U-SHOREFACE \\
\hline Ameghinomya argentina & & $\mathrm{R}$ & & & & & & & & C & & $\mathrm{C}$ & SINF & Suspension & SHOREF-INER-SHELF \\
\hline Ameghinomya meriodionalis & & & & & & & & & & $\mathrm{C}$ & & & SINF & Suspension & SHOREF-INNER-SHELF \\
\hline Pachymagas piramidesia & & C & & & & C & $\mathrm{R}$ & & & & & C & AT-EPI & Suspension & SHOREF-INNER-SHELF \\
\hline Panopea regularis & $\mathrm{R}$ & $\mathrm{R}$ & & & & & $\mathrm{R}$ & & & & & & INF & Suspension & FORE-SHOREF. \\
\hline Pteromyrtea danieli & & & & & & & $\mathrm{R}$ & & $\mathrm{R}$ & & & & INF & Suspension & FORE-SHOREF. \\
\hline Purpurocardia leonensis & c & $\mathrm{R}$ & & & & & $\mathrm{R}$ & & & & & & SINF & Suspension & FORE-SHOREF. \\
\hline Dosinia meridionalis & $\mathrm{R}$ & $\mathrm{R}$ & & & & & & & & C & & C & INF & Suspension & FORE-SHOREF. \\
\hline Dosinia elsai & & & & & & & & & & $\mathrm{C}$ & & & INF & Suspension & FORE-SHOREF. \\
\hline Pitaria ninfasiensis & & & & & & & & & & $\mathrm{C}$ & & C & INF & Suspension & FORE-SHOREF. \\
\hline Pitaria trigonus & & & & & & & & & & $\mathrm{C}$ & & $\mathrm{C}$ & INF & Suspension & FORE-SHOREF. \\
\hline Anomalocardia entrerriana & & & & & & & & & & $\mathrm{C}$ & & $\mathrm{C}$ & INF & Suspension & FORE-SHOREF. \\
\hline Chionopsis australis & & & & & & & & & & C & & C & INF & Suspension & FORE-SHOREF. \\
\hline Mactra sp. & & & & & & & & & & $\mathrm{C}$ & & $\mathrm{C}$ & INF & Suspension & FORE-SHOREF. \\
\hline Dinocardium novus & & & & & & & & & & $\mathrm{C}$ & & & SINF & Suspension & FORE-SHOREF. \\
\hline Cyrtopleura lanceol ata & & & & & & & & & & $\mathrm{C}$ & & & SINF & Suspension & FORE-SHOREF. \\
\hline Anadara lirata & & & & & & & & & & $\mathrm{R}$ & & $\mathrm{R}$ & SINF & Suspension & FORE-SHOREF. \\
\hline Trophon Iaciniatus & & $\mathrm{R}$ & & & & & & & $\mathrm{R}$ & & A & C & VAG-EPI & Carnivorous & FORE-SHOREF. \\
\hline Mytilus trigonus & & & & & & & $\mathrm{R}$ & & & & C & $\mathrm{R}$ & AT-EPI & Suspension & FORE-SHOREF. \\
\hline Eiptonium borcherti & & & & & & & & & & & C & & VAG-EPI & Carnivorous & FORE-SHOREF. \\
\hline Calliostoma spp. & & & & & & & & & & & $\mathrm{C}$ & & VAG-EPI & Carnivorous & FORE-SHOREF. \\
\hline
\end{tabular}




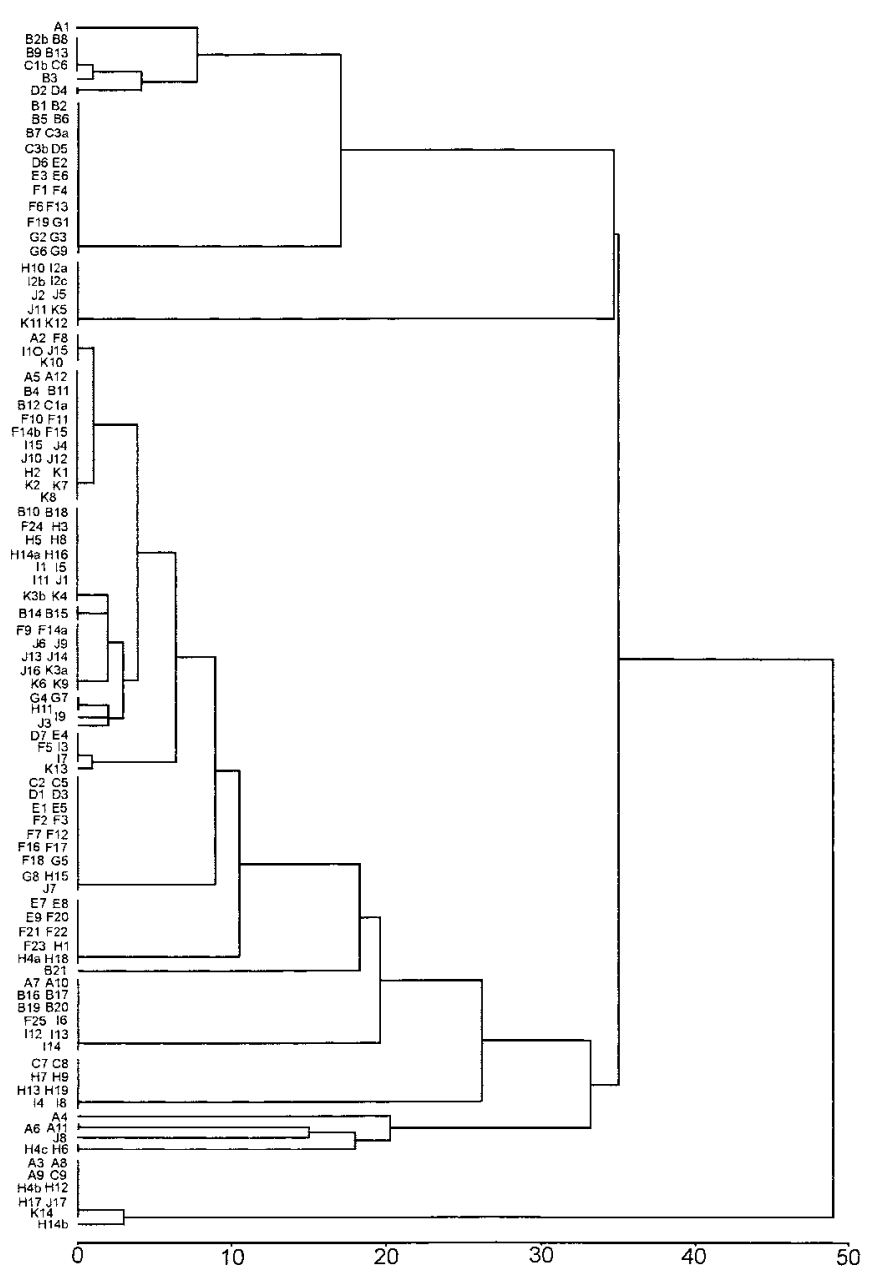

FIGURE 5-Cluster analysis from the data matrix shown in Appendix 1. Manhattan Distance, UPGMA.

(1975), ecological requirements of glycymerids remained stable from Cretaceous to Recent times. Thus, based on taphonomic features of these deposits, Assemblage GROT probably represents accumulations of indigenous benthic fauna on shell-gravel substrates in inner-to-mid-shelf environments swept by strong currents.

\section{Oysters, Chlamys actinodes, Aequipecten paranensis and "Turritella sp." (OCAT) Assemblage}

Taphonomic features of species that make up this assemblage are highly variable. Pectinid valves are mostly entire, and interior and exterior valve surfaces show variable degrees of infestation by clionid sponges, naticids (boreholes), and encrusting epibionts (serpulids, solitary corals, barnacles). Oysters are mostly articulated and do not show signs of encrusting or bioerosion. Bryozoan colonies are highly fragmented. In the lower coquinid at Eje Tentativo (Fig. 3) the Assemblage OCAT varies laterally from patches of $\mathrm{C}$. actinodes and $\mathrm{O}$. patagonica, in life position, to articulated but randomly oriented shells of these taxa, and finally to a highly disarticulated encrusted skeletal accumulation that reveals long residence time on the seafloor before final burial. Soft-bottom infauna include articulated shells as well as disarticulated valves of veneroids.

Modern counterparts of Chlamys actinodes and Aequipecten paranensis are the pectinids $C$. patagonica and $A$. tehuelcha, taxa widely distributed in the San J osé and Nuevo Gulfs adjacent to península Valdés (Fig.1), as well as in more open marine environments. In the latter setting, there is no overlap of bathymetric ranges of these taxa: C. patagonica occurs in depths ranging from 70 to $185 \mathrm{~m}$, while A. tehuedcha lives at depths from 30 to $60 \mathrm{~m}$ (Zaixo, 1996). In the more restricted environments of San J osé Gulf, both species inhabit shell-gravel or firm sandy bottoms in shallower waters than in the open Atlantic, and their bathymetric distribution ranges slightly overlap each other. Chlamys patagonica lives at depths from 30 to $90 \mathrm{~m}$ and Aequi pecten tehuel cha from 2 to $60 \mathrm{~m}$. According to Zaixo's data (1996), although Aequipecten tehuel cha tolerates low-to-moderate turbidity levels and may inhabit substrates affected by waves of the upper-shoreface zone, the densest populations are found in deeper settings like those of the inner-shelf, where they co-occur with theshallowest settlements of Chlamys patagonica. The latter species does not tolerate wave disturbance but prefers the strong currents of tide swept areas, like those at the gulf mouth, where the highest settlements of Chlamys patagonica are in patches oriented parallel to the tidal current flow. Taphonomic features of fossil Aequi pecten paranensis and Chlamys actinodes, along with the autoecology of their Recent congeneric species, suggest that this assemblage was indigenous to shell-gravel or firm sandy bottoms swept by tidal currents in shallow inner-to-mid-shelf settings, below fairweather wave base.

\section{Bryozoans, Oysters and “Turritella” sp. (BOT) Assemblage}

The dominant taxa in this assemblage are encrusting bilaminar cheilostome bryozoans (Aspidostoma sp., Celle pora sp., and Sertella sp. reteporid type). M ost of the shell beds are composed of small-to-moderate sized broken bryozoan colonies, sometimes including basal fixation surfaces. Oyster shells are disarticulated but unbroken, and turritelloids are represented by randomly-oriented internal molds.

The Recent bryozoan taxa that inhabit the Argentinian Shelf are probably the same species as the Miocene ones. Their ecological requirements are well known and similar to those of Chlamys patagonica; they inhabit firm substrates, fixed to small gravel or dead shells at depths ranging from 15 to $100 \mathrm{~m}$, in offshore areas swept by strong currents but devoid of turbidity and far bel ow fairweather wave base (Lopez Gappa, pers. comm., 1999). Erect colonies have deeper life habitats today on the Burwood Bank (Southern Atlantic Ocean) at 100 to $200 \mathrm{~m}$ in areas strongly swept by currents. According to Lopez Gappa (pers. comm., 1999), although bryozoans have not yet been found living in the San J osé and Nuevo Gulfs of the study area, their ecological requirements are the same as those of the Chlamys patagonica community, and they should be associated in the same areas at the gulf mouth where the densest populations of $C$. patagonica are recorded. Thus, autoecological data point to a current-swept inner-to-midshelf environment as the probable setting for Assemblage BOT. 


\section{Amusium paris and Ostrea patagonica (AO) Assemblage}

Three taphofacies are recognized within this assemblage (Table 2): (1) Multi-event, time-averaged accumulations with erosive lower contacts; (2) single-event, timeaveraged concentrations; and (3) census assemblages. Single-event and census accumulations form concentrations with no defined lower contacts and consist of the rediner ecophenotype of $\mathrm{O}$. patagonica in life position, changing laterally to concentrations of articulated Amusium paris. There is no evidence of exhumation; instead, a sudden entombing event is inferred, proceeded by a low-energy hydraulic event that removed Amusium from life position but did not affect the heavier oyster shells. Concentrations of this type are fairly common in the San J osé and L ote 39 sections. At these sites, $3 \mathrm{~m}$ of muddy, highly bioturbated strata contain dispersed and randomly oriented articulated shells of Amusium, with no exhumation features. The accumulations are inferred to have been originally census assemblages that were later bi oturbated. Thin intercalations of Assemblage $\mathrm{AO}$ and $\mathrm{OS}$ also are common and indicate a lateral transition between the assemblages.

Autoecological references of congeneric Recent species and the pal eoecological significance of this assemblageare discussed in the following section (Assemblage AOA and CAF).

\section{Pectinid and Oyster (CAF and AOA) Assemblages}

Assemblages AOA and CAF are usually found in vertical succession, but lateral transitions between them also are recorded frequently. Both assemblages have erosive lower contacts, are capped by a pavement of Assemblage OS or GROT, and lie on thin census accumulations of Assemblage MO.

As it is shown in Table 2, Assemblage AOA occurs as two taphofacies: multi-event concentrations (Fig.7) and census accumulations (Fig. 8). The latter accumulations are not common, but a good example occurs to the east of the Lote 39 section. This consists of a thin, muddy, matrixsupported accumulation of Ostrea patagonica (bunched ecophenotype) and clumps of Aequipecten paranensis and Pachymagas piramidesia in life position. This is the only record of Aequi pecten paranensis clumps with shells in upright-living position, inclined on the right (byssated) valve. Most specimens of Amusium paris are articulated and recline on their right valves, but a moderate percentage of shells have been overturned and some are oriented vertically. The muddy matrix is densely penetrated by large-diameter burrows, and bioturbators are considered to have been responsible for overturning the Amusium valves.

According to autoecological data of congeneric Recent species, it is inferred that the various pectinid taxa probably differed in ecological requirements. Based on the ecological requirements of Recent Amusium balloti and Amusium japonicum (Heald and Caputi, 1981; J oll, 1988, 1989), the Miocene A. paris probably occupied lower-shoreface-to-inner-shelf sandy bottoms, above or below fairweather wave base, swept only by low or moderately low tidal currents. Recent Flabelipecten species are adapted to variable energy, substrata, and depth conditions. Consequently, no paleoecologic inferences can be made with confidence for the fossil taxa. Paleoecologic inferences made by Bernasconi and Robba (1993) on a similar Miocene assemblage from Italy, where Flabellipecten burdigalensis, Amusium cristatum, and Pecten fuchsi dominate the fossil community, placed this assemblage in a shallow, low-energy, slightly offshore shoal environment, swept by currents and/or influenced by wave action, at approximately 10-12 m water depth (Bernasconi and Robba, 1993, p. 281, 283). This environment is similar to that of modern Amusium and is consistent with sedimentologic features of the sequence. The Amusium paris-F label li pecten piramidesensis assemblage also is considered to have inhabited sandy bottoms in shallower environments than Chlamys actinodes, either above or just bel ow fairweather wave base, where currents are low to moderate and wave motion is slight, in the lower shoreface-to- inner-shelf zones. According to paleoecological data inferred in this paper (see Assemblage OCAT), Aequipecten paranensis was associated with both Amusium paris and Flabel lipecten piramidesensis in shallower waters as well as with Chlamys actinodes in deeper ones. Taking into account its stratigraphic succession with Assemblage MO (discussed below), and based on the presence of indigenous material from different substrates, as well as from variable depths and energy conditions, amalgamated deposits of the Assemblage CAF, AOA, and MO are considered as environmentally condensed shell beds whose origins will be fully discussed in the following section.

\section{Monophoraster and Oysters (MO) Assemblage}

The MO Assemblage is very common in the Regressive Phase and Monophoraster darwini and the recliner ecophenotype Ostrea patagonica, occur both separately and intermixed with each other.

Census accumulations consist of hardparts that "float" either in an ochreous, massive, medium-to-fine sandy matrix or in thesandy portions of gray heterolithic beds. They are overlain by a strongly bioturbated Skolithos and Ophiomorpha I chnofacies that constitutes the base of the overlying Assemblage CAF-AOA. The echinoid assemblage commonly grades laterally into oyster accumulations in life position. Single-event concentrations can intergrade laterally with the $\mathrm{V}, \mathrm{AO}$, and $\mathrm{MZ}$ Assemblages. Multi-event concentrations of disarticulated and entireosyter val ves and fragmented M. darwini infill large erosive tidal channels.

The closest living relatives of $\mathrm{M}$. darwini are the mellitid sand dollars (Mooi et al., 2000), which range along the western Atlantic Ocean south to the Río de la Plata (Argentina). Mellitids can be found in dense populations in clean, sandy bottoms in high-energy coastal environments. Species of Melita, in particular, usually occur as densely populated bands approximately $100 \mathrm{~m}$ seaward from the wave-breaking zone, in the shoreface zone at depths of up to $10 \mathrm{~m}$ (Mooi, pers. com., 1999). Because of their occurrence in a high-energy environment, tests of dead individuals are reworked and usually immediately broken after death, except when rapidly buried by sediment associated with storm events that can rearrange beach topography. The Miocene Monophoraster seems to have inhabited environments, and very likely exhibited behaviors, that were similar to those of modern mellitids. 
TABLE 2-Taphonomic features of Fossil Assemblages. Stratigraphic distribution: $\mathrm{T}=$ Transgressive Phase; $\mathrm{MH}=\mathrm{Maximum}$ Highstand Phase; $R=$ Regressive Phase; Taphonomic features-ms = matrix-supported; ss = shell-supported; $L=$ low, $M=$ medium; $H=$ high.

\begin{tabular}{|c|c|c|c|c|c|}
\hline \multirow[b]{2}{*}{$\begin{array}{l}\text { Assemb- } \\
\text { lages }\end{array}$} & \multirow[b]{2}{*}{$\begin{array}{l}\text { Stratigraphic } \\
\text { distribution }\end{array}$} & \multirow{2}{*}{$\begin{array}{l}\text { Association } \\
\text { w/other } \\
\text { assemblages }\end{array}$} & \multirow[b]{2}{*}{ Type of shell-concentrations } & \multicolumn{2}{|c|}{ Taphonomic features } \\
\hline & & & & $\begin{array}{l}\text { Close } \\
\text { packing }\end{array}$ & Fragmentation \\
\hline OS & T-MH-R & $\begin{array}{l}\text { GROT-OCAT- } \\
\text { AO-MO-CAF- } \\
\text { OMA-MOT- } \\
\text { AOA }\end{array}$ & $\begin{array}{l}1-0.1 \mathrm{~m} \text { census (highly frequent) } \\
2-0.1 \mathrm{~m} \text { autochthonous single-event, time-averaged } \\
3-0.8 \mathrm{~m} \text { allochthonous multi-event, time-averaged }\end{array}$ & $\begin{array}{l}1-\mathrm{ms} \\
2-\mathrm{ss} \\
3-\mathrm{ss}\end{array}$ & $\begin{array}{l}\text { 1-none } \\
2-\mathrm{L} \\
3-\mathrm{H}\end{array}$ \\
\hline GROT & $\begin{array}{l}1-\mathrm{T} \\
2-\mathrm{MH}-\mathrm{R}\end{array}$ & $\begin{array}{l}\text { OCAT-BOT } \\
\text { OS-CAF } \\
\text { AOA }\end{array}$ & $\begin{array}{l}1-3 \mathrm{~m} \text { autochthonous multi-event, time-averaged } \\
\text { 2-0.1 m autochthonous single-event, time-averaged } \\
\text { (pavements) }\end{array}$ & $\begin{array}{l}1-\mathrm{ss} \\
2-\mathrm{ms}\end{array}$ & $\begin{array}{l}\text { 1-none } \\
2-\text { none }\end{array}$ \\
\hline OCAT & $\mathrm{T}-\mathrm{MH}$ & $\begin{array}{l}\text { GROT-BOT } \\
\text { OS }\end{array}$ & 0.3-0.5 m autochthonous within-habitat, single-event & ss & $\begin{array}{l}\text { variable } \\
\quad \text { (see text) }\end{array}$ \\
\hline BOT & $\mathrm{T}-\mathrm{MH}$ & $\begin{array}{l}\text { OCAT-GROT } \\
\text { OS }\end{array}$ & up to $0.4 \mathrm{~m}$ parautochthonous multi-event & ss & see text \\
\hline $\mathrm{AO}$ & T-R & $\begin{array}{l}\text { AOA-CAF } \\
\text { OS-MO }\end{array}$ & $\begin{array}{l}\text { 1-0.1 m census (unfrequent); } 2-0.4 \mathrm{~m} \text { autochthonous } \\
\text { single event, within-habitat, time averaged; } 3-0.2 \\
\text { multi-event, time-averaged }\end{array}$ & $\begin{array}{l}1-\mathrm{ms} \\
2-\mathrm{ms} \\
3-\mathrm{ms}\end{array}$ & $\begin{array}{l}1-\text { none } \\
2-L \\
3-L\end{array}$ \\
\hline CAF & $\mathrm{R}$ & $\begin{array}{l}\text { AO-OS } \\
\text { MO-AOA }\end{array}$ & $\begin{array}{l}0.6 \mathrm{~m} \text { autochthonous multi-event environmentally con- } \\
\text { densed }\end{array}$ & ss & none-L \\
\hline AOA & $\mathrm{R}$ & $\begin{array}{l}\text { CAF-OS } \\
\text { AO-MO }\end{array}$ & $\begin{array}{l}1-3 \mathrm{~m} \text { autochthonous time-averaged multi-event } \\
2-0,2 \mathrm{~m} \text { census (unfrequent) }\end{array}$ & $\begin{array}{l}1-\mathrm{ss} \\
2-\mathrm{ms}\end{array}$ & none \\
\hline MO & $\mathrm{R}$ & $\begin{array}{l}1-C A F-O S \\
2-A O-A O A \\
3-V-M Z-A O A\end{array}$ & $\begin{array}{l}\text { 1-up to } 0.04 \mathrm{~m} \text { census (highly frequent) } \\
2-0.3 \mathrm{~m} \text { autochthonous single-event, time-averaged } \\
3-0.3-0.5 \mathrm{~m} \text { allochthonous multi-event }\end{array}$ & $\mathrm{ms}$ & $\begin{array}{l}1-\text { none } \\
2-\mathrm{M} \\
3-\mathrm{H}\end{array}$ \\
\hline OMA & $\mathrm{R}$ & MO-OS-V & $0.3 \mathrm{~m}$ allochthonous single-event & $\mathrm{ms}$ & $\begin{array}{l}\text { variable } \\
\quad \text { (see text) }\end{array}$ \\
\hline $\mathrm{V}$ & $\mathrm{R}$ & AO-MO & $\begin{array}{l}1-0.2 \mathrm{~m} \text { census (unfrequent) } \\
2-\text { up to } 0.3 \mathrm{~m} \text { autochthonous single-event }\end{array}$ & $\begin{array}{l}1-\mathrm{ms} \\
2-\mathrm{ss}\end{array}$ & none-L \\
\hline МOT & $\mathrm{R}$ & OMA-OS-V & $0.1 \mathrm{~m}$ allochthonous time-averaged & ss & $\mathrm{M}-\mathrm{H}$ \\
\hline MZ & $\mathrm{R}$ & CAF-V & $0.4 \mathrm{~m}$ autochthonous multi-event, time-averaged & ss & $\mathrm{M}-\mathrm{H}$ \\
\hline
\end{tabular}

Therefore, for M. darwini, a shallow and very high-energy environment with strong wave action over clean sandy bottoms is inferred. As this species was only a shallow burrower that feeds on (or just below), the sediment surface, rapid and deep burial of the population by storm sediments would prevent the echinoids from reattaining the surface. Both extant sand dollars and M. darwini almost always occur as monospecific assemblages. The lack of mixing with other species and the preservation in life position, with the oral surface directed downwards, support the idea that populations of M. darwini were catastrophically buried. Monophoraster co-occurs with oysters only in tidal channel deposits, where both have been reworked post-mortem. Thereclining oyster O. patagonica apparently lived on sands exposed to less direct wave action and lateral to echinoid habitats. Oyster, Monophoraster darwini, and Aequi pecten paranen-
sis (OMA) Assemblage

This assemblage constitutes shell beds with erosivelower contacts. Oysters are unbroken but have a high proportion of disarticulated valves; tests of Monophoraster are highly fragmented; and pectinid shells are strongly sizeand right-left valve sorted, may be entire or fragmented, have eroded margins, and moderate to poorly preserved ornamentation, and are highly bored and infested. This assemblagecommonly overlies thin, time-averaged or census assemblages of Assemblage MO and is capped by census concentration of Assemblage OS. According to the life habitats for these taxa (discussed above), Assemblage OMA records accumulations in high-energy shoreface environments where $\mathrm{M}$. darwini was probably theonly taxon adapted to local conditions. E cologically disparate forms and different sources of shells, in addition to the large extent of boring, rounding, and fragmentation of shells from different environments and substrata, indicate that these shells largely accumulated out of their habitat after having suffered transport and prolonged exposure on the seafloor.

\section{Veneroid (V) Assemblage}

Taxonomic composition and taphonomic features of each shell bed of this assemblage is usually variable (see Table 2 and Appendix 1). This assemblage occurs infrequently in the Regressive Phase at Bajo de Madryn and in those sections east of Puerto Pirámide.The San J osé section records low-diversity census assemblages "floating" in a gray, very fine sandstone and is composed of clumps of unsorted articulated P. rostrata mutabile Mactra sp., and P. regularis in life position. AssemblageV is represented at the Bajo de Madryn section by thin, single-event shell beds with erosive lower contacts that are intercalated with 
TABLE 2-Continued

\begin{tabular}{|c|c|c|c|c|c|c|}
\hline \multirow[b]{2}{*}{$\begin{array}{l}\text { Assem- } \\
\text { blages }\end{array}$} & \multicolumn{6}{|c|}{ Taphonomic features } \\
\hline & Abrasion & $\begin{array}{l}\text { Disarticu- } \\
\text { lation }\end{array}$ & Encrusting & Bioerosion & Orientation & $\begin{array}{l}\text { Size } \\
\text { Sorting }\end{array}$ \\
\hline OS & $\begin{array}{l}\text { 1-none } \\
2-\mathrm{L} \\
3-\mathrm{H}\end{array}$ & $\begin{array}{l}\text { 1-art. } \\
\text { 2-art./dis. } \\
\text { 3-dis. }\end{array}$ & $\begin{array}{l}\text { 1-none } \\
2-\mathrm{L} \\
3-\mathrm{H}\end{array}$ & $\begin{array}{l}\text { 1-none } \\
2-\mathrm{L} \\
3-\mathrm{H}\end{array}$ & $\begin{array}{l}\text { 1-bunched or recliner shells in life } \\
\text { position; } 2 \text {-convex up \& down; } 3- \\
\text { chatoic }\end{array}$ & $\begin{array}{l}1-\mathrm{L} \\
2-\mathrm{M}-\mathrm{H} \\
3-\mathrm{H}\end{array}$ \\
\hline GROT & $\begin{array}{l}\text { 1-none } \\
2 \text {-none }\end{array}$ & $\begin{array}{l}\text { 1-art./dis. } \\
\text { 2-art./dis. }\end{array}$ & $\begin{array}{l}\text { 1-none } \\
2 \text {-none }\end{array}$ & $\begin{array}{l}\text { 1-none } \\
\text { 2-none }\end{array}$ & $\begin{array}{l}\text { 1-chaotic } \\
\text { 2-concordant }\end{array}$ & L \\
\hline OCAT & $\mathrm{L}$ & $\begin{array}{l}\text { art./dis. pectin- } \\
\text { ids; art. oys- } \\
\text { ters \& vene- } \\
\text { roids }\end{array}$ & see text & see text & pectinids \& oyster stacked or chaotic & M \\
\hline BOT & see text & see text & none & none & chaotic & \\
\hline $\mathrm{AO}$ & none & $\begin{array}{l}\text { 1-art. } \\
\text { 2-dis. } \\
\text { 3-dis. }\end{array}$ & $\begin{array}{l}1-\text { none } \\
2-\text { none } \\
3-M\end{array}$ & none & $\begin{array}{l}\text { 1-life position } \\
2-3 \text { stacked Amusium \& concordant } \\
\text { oysters }\end{array}$ & L \\
\hline CAF & M & $\begin{array}{l}\text { dis. pectinids } \\
\& \text { osyters; } \\
\text { art. vene- } \\
\text { roids }\end{array}$ & $\mathrm{H}$ & $\mathrm{H}$ & $\begin{array}{l}\text { stacked pectinids; convex up \& down } \\
\text { oysters; chaotic brachiopods \& ve- } \\
\text { neroids }\end{array}$ & $\mathrm{H}$ \\
\hline AOA & none-L & $\begin{array}{l}\text { 1-dis./art. } \\
\text { 2-art. }\end{array}$ & none-L & none-L & $\begin{array}{l}\text { 1-chaotic or stacked } \\
\text { 2-life position }\end{array}$ & $L-M$ \\
\hline MO & $\begin{array}{l}\text { 1-none } \\
2-\mathrm{M} \\
3-\mathrm{H}\end{array}$ & 3-dis. oysters & none & none & $\begin{array}{l}\text { 1-life position w/aboral side up } \\
\text { 2-chaotic } \\
\text { 3-chaotic }\end{array}$ & $\begin{array}{l}1-\mathrm{L} \\
2-\mathrm{M}-\mathrm{H} \\
3-\mathrm{H}\end{array}$ \\
\hline OMA & see text & see text & see text & see text & chaotic & $\mathrm{H}$ \\
\hline V & none-L & $\begin{array}{l}\text { 1-art } \\
\text { 2-dis }\end{array}$ & none & none & $\begin{array}{l}\text { 1-clumps in life position } \\
2 \text {-chaotic or imbricated }\end{array}$ & $\begin{array}{l}1-\mathrm{L} \\
2-\mathrm{H}\end{array}$ \\
\hline MOT & M & dis & $\mathrm{M}-\mathrm{H}$ & $\mathrm{M}-\mathrm{H}$ & chaotic & $\mathrm{H}$ \\
\hline$M Z$ & $\mathrm{M}-\mathrm{H}$ & dis & $M$ & $M$ & chaotic & $\mathrm{M}-\mathrm{H}$ \\
\hline
\end{tabular}

time-averaged, highly fragmented accumulations of Assemblage MO. These concentrations exhibit a well-ordered, oblique fabric of sorted, entire, and disarticulated right valves of $\mathrm{P}$. rostrata mutabile and $\mathrm{D}$. meridionalis (Fig.9). Other types of shell beds are constituted by a highly diverse assemblages where almost all veneroids and arcoids species are present (Puerto Piramide's section).

According to ecological data obtained from congeneric

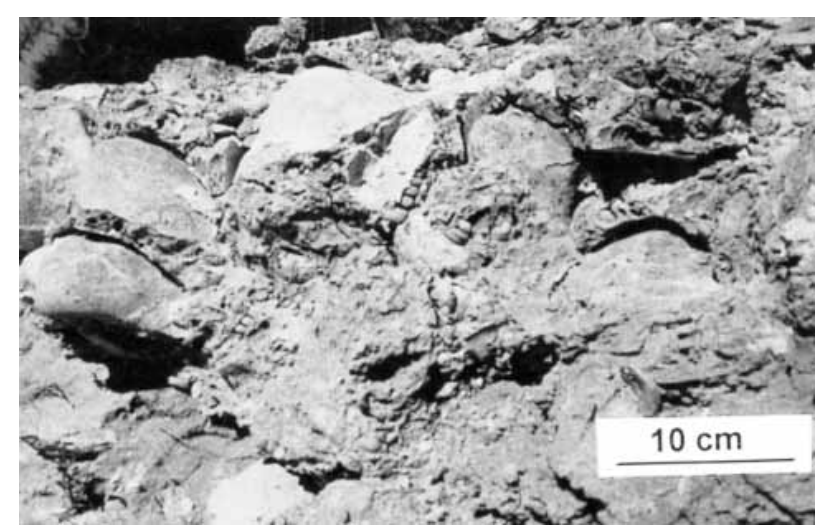

FIGURE 6-Assemblage GROT at El Doradillo, dominated by disarticulated valves of Glycymerita magna and Ostrea patagonica and turritelloid molds. species living in the area (P. rostrata, Amiantis purpuratus) and closest relatives (Chionopsis, Dosinia, Panopea), this fossil assemblage is inferred to have inhabited soft substrates in intertidal to shoreface settings (Villaverdeet al., 1974; Zaixo, 1975; Escofet et al., 1978; Abbott and Dance, 1986).

Trophon Iaciniatus, Mytilus trigonus and Oysters (MOT) Assemblage

The Recent closest relatives from the study area, Epitonium orbigny, Mytilus edulis, and Trophon geversianus, inhabit hard-bottom settings ranging from intertidal to shoreface zones, but are most abundant in intertidal environments (Olivier et al., 1966; Zaixo, 1975).

\section{Mixed (MZ) Assemblage}

Mixed assemblages are those characterized by representatives from more than one of the assemblage defined above. Taphonomic features of these accumulations indicate that fossils were transported from different substrates and depths, and later accumulated out of their original life habitat resulting in the admixtures of different ecological forms. These concentrations commonly infill large erosive tidal channels and also make up the complex 


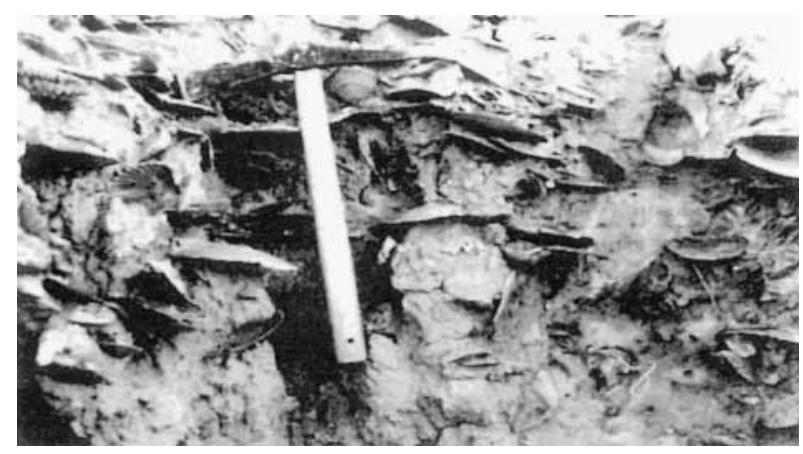

FIGURE 7-Time-averaged accumulation of Assemblage AOA, showing entire, and disarticulated valves of Amusium paris, Aequipecten paranenis, and Ostrea patagonica at Eje Tentativo Ob.

shell beds at top of the study sequence (sections San J osé, Lote 39, Puerto Pirámide).

\section{ASSEMBLAGE ASSOCIATIONS AND GENERAL SEDIMENTARY ENVIRONMENTS}

Q-Mode Cluster analysis (Manhattan distance, UPGMA figured, but with minor differences applying Euclidean, Squared Euclidean distances indexes, and complete, simple and WPGMA linkages) (Fig.10), based on relative frequencies of species, defines three main groups of assemblages: (1) OCAT and GROT; (2) V and MZ; and (3) BOT, OS, AO, MO, OMA, AOA, and MOT. In this latter group, assemblages OS, AO, and $\mathrm{MO}$ are closely tied together and are more related to BOT than the remaining assemblages. This group reflects the large influence of oysters, which strongly influence the clustering of Assemblage $\mathrm{AO}, \mathrm{OS}$, and $\mathrm{MO}$. A distinctive lateral and vertical transition between assemblages $\mathrm{MO}$ and $\mathrm{OS}$ al so occurs in several sections (Fig. 3). Assemblage CAF, with a low similarity value, clusters with the first two groups defined above, probably due to the presence of the same pectinid species that constitute CAF and theremaining assemblages.

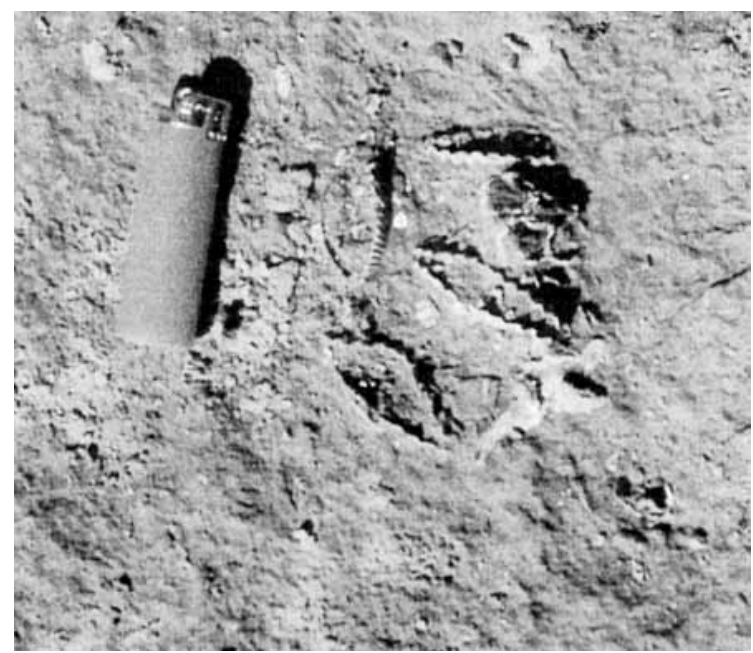

FIGURE 8-Cluster of vertically-oriented, articulated Aequipecten paranensis in life-position, representing accumulation of Assemblage AOA at the Regressive Phase, near Lote 39.

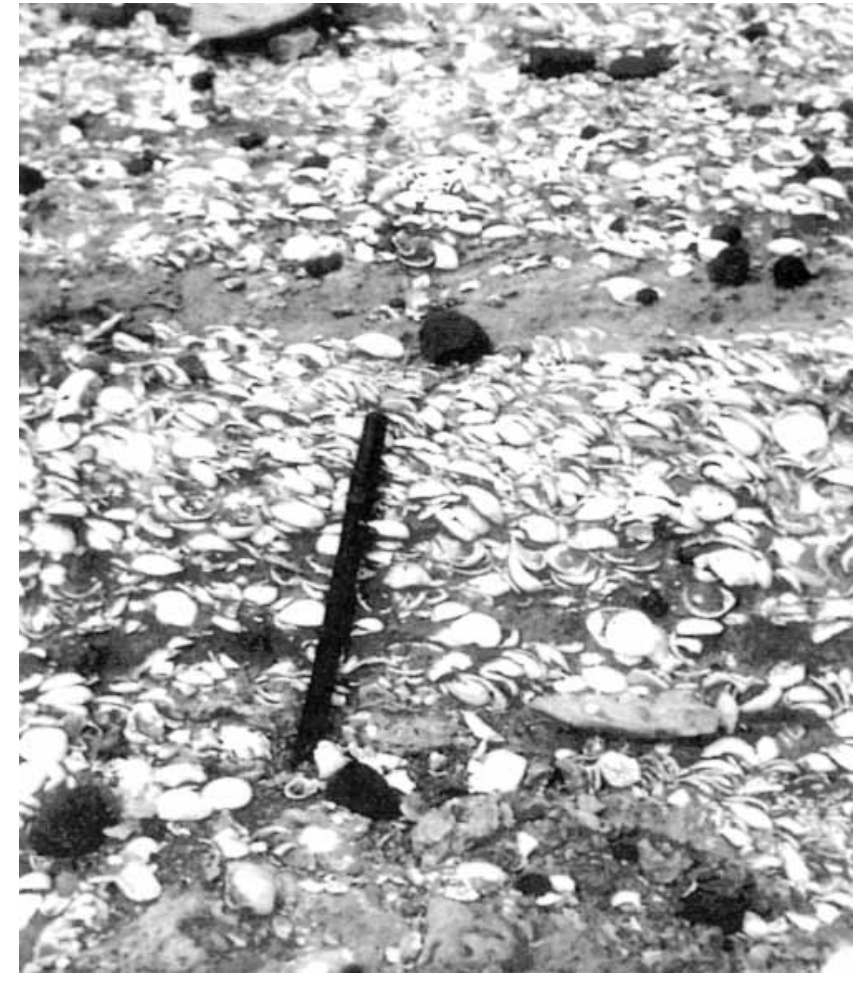

FIGURE 9-Single-event, time-averaged accumulation of hydraulically-oriented, disarticulated valves of Pitaria mutabile of Assemblage V at Bajo de Madryn.

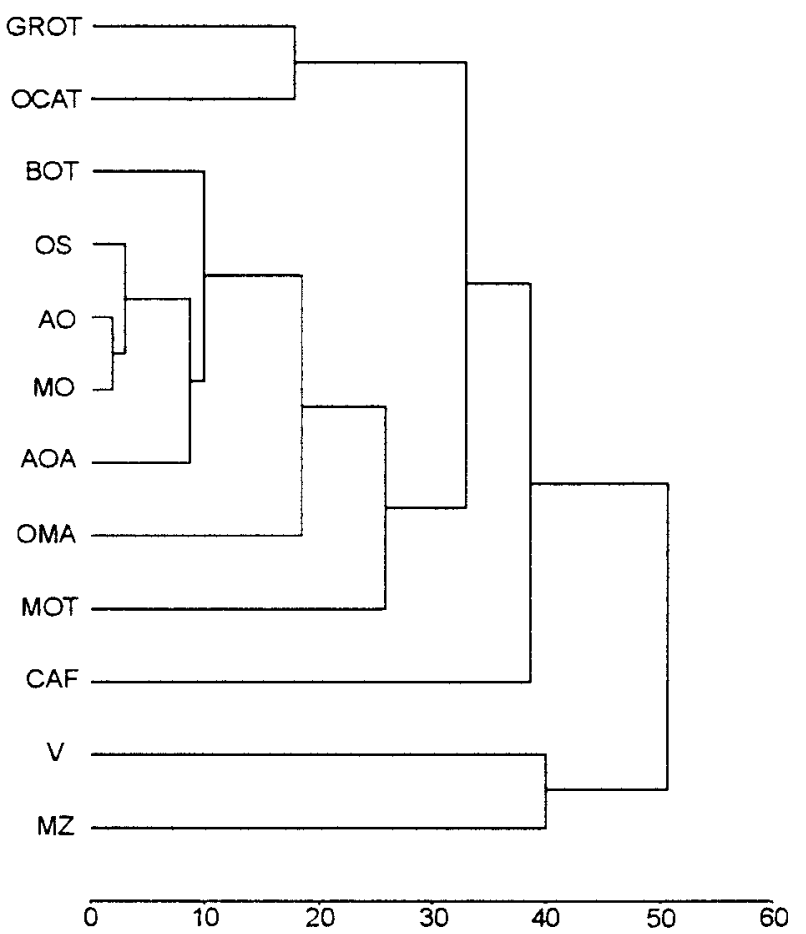

FIGURE 10-Dendogram illustrating association of assemblages based on cluster analysis (UPGMA) using Manhattan Distance indexes (data matrix in Table 1). 
The results from cluster analysis, along with the vertical and lateral relations observed among assemblages in outcrops (Fig. 3), are used to define three assemblage associations. Association A is composed exclusively of GROT, OCAT, BOT, and OS Assemblages. It is restricted to the lowermost $30 \mathrm{~m}$ of the sequence (Fig. 3) and is present in the Transgressive Phase of most analyzed sections (although it is not clearly identified in the Bajo de Madryn section where only thin accumulations of Assemblage GROT were recognized). Association A is composed of amalgamated, indigenous fossiliferous accumulations with a distinct, complex internal stratigraphy of successive assemblages.

Association $B$ is only recorded in sections east of EI Doradillo and is characterized by vertical succession of recurrent census concentrations of: (1) Assemblages MO and OS; overlain by (2) autochthonous-parautochthonous, environmentally condensed accumulations of Assemblages AOA, CAF, AO, and OS; and capped by (3) a thin pavement of Assemblage GROT.

Association $C$ is made up by the cluster of OMA, MOT, $\mathrm{V}$, and $\mathrm{MZ}$, with a minor participation of Assemblages OS and MO. These assemblages occur individually in thin, concentrations that "float" in barren intervals, or in thin single-event shell beds with erosivelower contacts, or constitute large tidal-channel infillings where shells are pervasively broken. An exception to this is the appearance of the MZ Assemblage at the top of the complex shell beds that tops Cycle III of the Regressive Phase (see below). With the exception of a census accumulation of Assemblage $\mathrm{V}$ at the San J osé section, shells in Association $\mathrm{C}$ show evidence of transport out of the original life habitat and long exposure times on seafloor before burial. Association $C$ constitutes the only fossil assemblages recovered from exposures west of EI Doradillo, where the study sequence consists of the shallowest marine lithofacies re corded in the basin.

\section{RECONSTRUCTION OF THE MIOCENE LIVING ASSEMBLAGES}

Base on (1) the dominance of exceptionally well pre served, time-averaged, within-habitat accumulations (indigenous material), (2) the accurate paleoecologic data provide by autoecological comparison with Recent relatives, many of which inhabit the modern Patagonian littoral zone, and (3) the integration of sedimentologic and paleoecological inferences, the shelly benthic communities that inhabited the study area during Miocenetimes can be reconstructed with high confidence (Fig. 11).

Shell-gravel substrates from inner-to-mid-shelf settings, placed below the fairweather wave base but swept by strong tidal currents, would have been the proper environments for the settlement of the suspension-feeders Chlamys actinodes, Glycymerita magna, Aequipecten paranensis, Retrotapes ninfasiensis, and bunched oysters. These species were probably the dominant shell-producing epifaunal and semi-infaunal dwellers. In similar water depths but in a lower-energy environment, settlement of erect bryozoan colonies took place. The taxonomic composition of these living assemblages is partially coincident with that of the fossil assemblages BOT, OCAT, and GROT and, in this way, Association A undoubtedly repre-

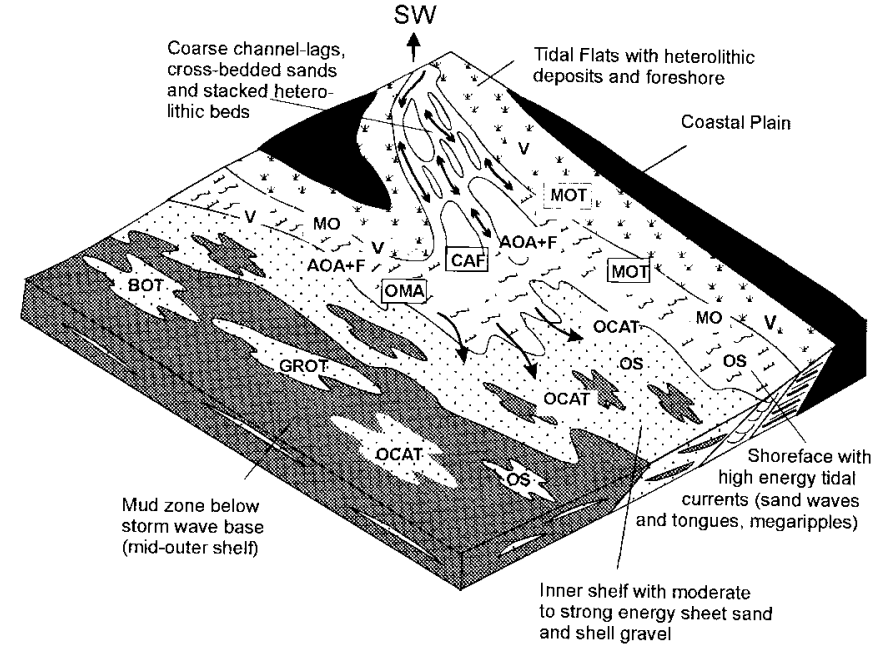

FIGURE 11-Reconstruction of spatial distribution of benthic assemblages in the Miocene Puerto Madryn Formation. Fossil assemblages BOT, GROT, OCAT, MO, AOA, and $\mathrm{V}$ are coincident with living communities and are bathymetrically placed where they actually lived. Assemblages CAF, MOT and OMA do not represent living assemblages and are plotted in settings where they accumulated; CAF is an environmental assemblage that involved taxa from mid-inner shelf settings (Chlamys actinodes), and Flabellipecten piramidesensis from shoreface environments (see text); OMA and MOT are allochthonous assemblages; AOA + F = living Flabellipecten piramidesensis associated with Amusium paris, Ostrea patagonica, and Aequipecten paranensis and forming part of a same living community. Enviromental diagram modified from Levell (1980), and Johnson and Baldwin (1996).

sents an inner- to mid-shelf assemblage characteristic of relatively high energy and clear water conditions.

In shallower environments of the shoreface and innershelf cl ose to fair weather wave base, the suspension-feeders Ostrea patagonica, Aequipecten paranensis, Amusium paris, and Flabellipecten piramidesensis dominated benthic communities in soft sandy or muddy bottoms affected only by weak tidal currents and wave motion. Species of Ostrea, Amusi um, and Aequipecten constituted a living association similar to that of the fossil AOA and AO Assemblages. Flabelipecten is recovered from the condensed CAF Assemblage that does not represent any singleliving community. Instead, taxa from very different bathymetric settings co-occur.

Clean sandy soft bottoms from upper-shorefacesettings, situated just seaward of the breaking wave zone, were inhabited by a low-diversity assemblage dominated by the vagile deposit feeder Monophoraster darwini and the re clining suspension feeder Ostrea patagonica. This coincides with the fossil MO Assemblage.

F oreshore and upper-shoreface settings were inhabited by shallow and deep infaunal suspension feeders (vene roids) in soft sandy seafloors, whilevagilecarnivorous gastropods (E pitonium borcherti, Trophon laciniatus) and sessile suspension feeders (Mytilus trigonus) settled down on locally firm substrates. The veneroids living association is represented by the fossil Assemblage $\mathrm{V}$. The remaining taxa are recovered from the fossil allochthonous assemblages MOT, OMA, and MZ.

Aequipecten paranensis and the various oysters, which are the most common taxa in the Puerto Madryn fauna, 


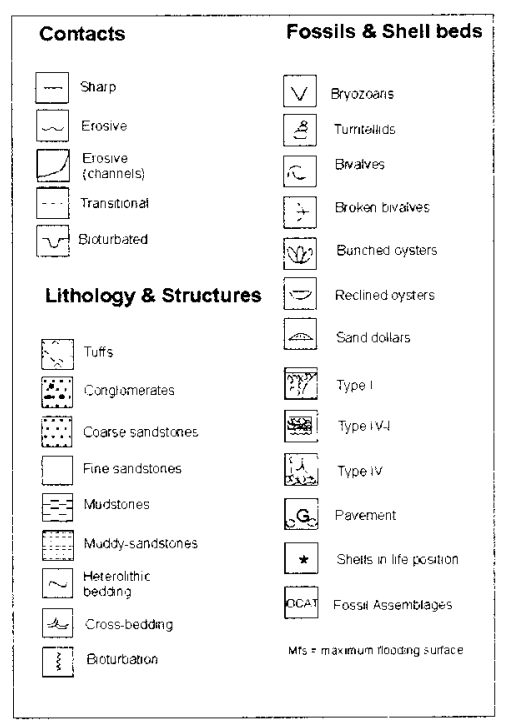

REGRESSIVE

PHASE

CYCLE II

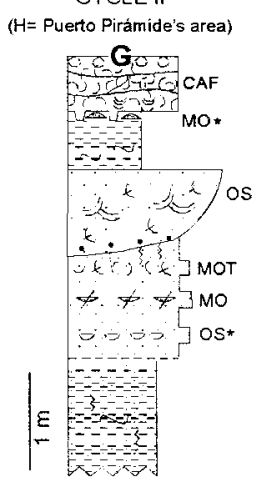

UPPER SHELL-BED ( $F=$ Eje Tentativo $O b$ )

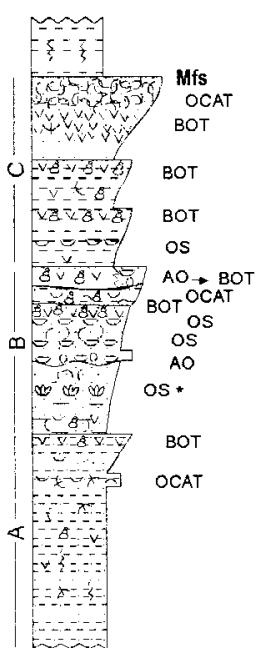

FIGURE 12-Schematic stratigraphic columns showing detailed taphonomic aspects and vertical distribution of assemblages in the Lower shell bed, Middle shell bed, and Upper shell bed of the Transgressive Phase and cycles of the Regressive Phase.

are present in almost all assemblages. Taking intoaccount the ecology of their closest living relatives, these Miocene taxa were probably associated with fossil accumulations deposited in a wide depth range and energy conditions within the shoreface and inner shelf (i.e., they were eurytopes).

\section{TAPHONOMY AND STRATIGRAPHY OF SHELL BEDS}

According to Kidwell's terminology (1986), and reflecting changes in net sedimentation/shell input rate, complex shell beds in the Puerto Madryn Formation are of three types: (1) Type I shell beds, which display an upwards increase in shell-packing density and terminate in an omission (non-erosional) bedding surface; (2) Type IV shell beds, which have a sharp erosive lower contact and grade upwards from shell-supported to matrix-supported fabric; and (3) composite Type IV-I shell beds with both lower and upper sharp contacts and with internal discontinuities usually well developed.

\section{Transgressiveand Maximum Highstand Phases}

The Transgressive Phase comprises threemain complex shell beds: these are labeled the lower [LSB], middle [MSB], and upper [USB] shell beds in Figure 3. Each records a vertical recurrence of assemblages BOT, OCAT, OS, and GROT (Association A), with a slight upsection increase in the importance of Assemblage $A O$ and a gradual disappearance of Assemblage GROT. Detailed internal discontinuities and fossil assemblage distribution are illustrated in Figure 12.

The Lower shell bed [LSB] directly overlies the "Patagonian beds." The top of the "Patagonian beds" is oxidized, enriched in phosphates, and bears the Glossifungites ichnoassemblage. The thickness of the LSB varies from a $3 \mathrm{~m}$ thick, slightly amalgamated, multi-event Type IV shell bed at Las Charas (Fig. 13) to a 0.3- m- thick, strongly amalgamated, composite Type IV-I shell bed at Eje Tentativo Ob and EI Doradillo. At thesetwo localities, the LSB also bears phosphatic concretions, marine mammal remains, shark teeth, regular echinoids spines, intraclasts 


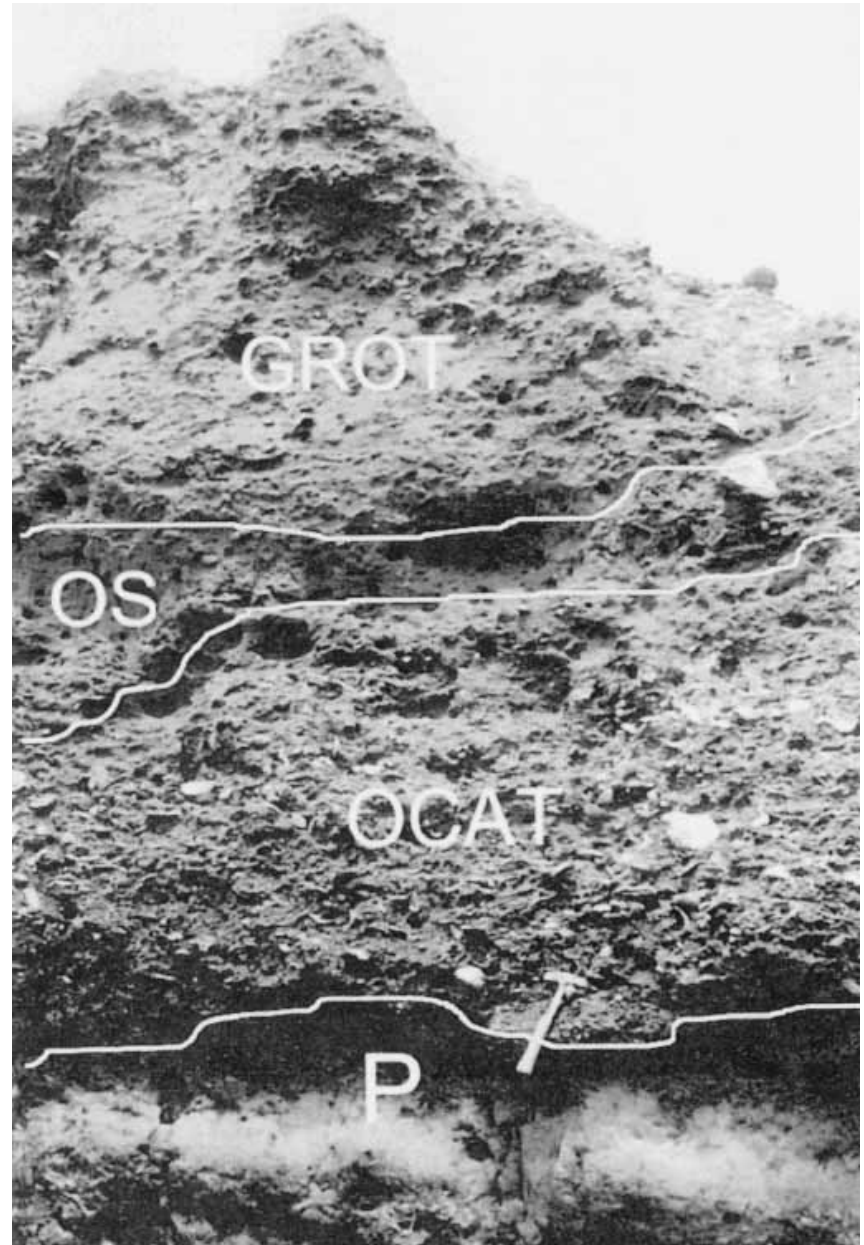

FIGURE 13-Lower complex shell bed of the Transgressive Phase at Las Charas, showing two Type IV shell beds with erosive lower and transitional upper contacts, yielding time-averaged, within-habitat and shell-supported accumulations of assemblage OCAT, GROT, and OS . The shell beds are underlain by the "Patagonian beds."

and terrigenous gravels. The LSB is overlain by $5 \mathrm{~m}$ of unfossiliferous ochreous, cross-bedded sandstones, or massive highly bioturbated silty sandstones from shoreface to inner-shelf settings.

The Middle shell bed [MSB] (Figs. 12, 14) is a 3-m-thick, highly-amalgamated composite Type IV-I fossiliferous unit that can be correlated over $30 \mathrm{~km}$, and terminates in a pavement of Assemblage GROT. The LSB and MSB are both multi-event, time-averaged, shell-supported accumulations and their taphonomic features are those described for Assemblage OCAT, GROT, and BOT, indicating long time exposure on the seafloor with negligible transport of shells out of habitat.

The Upper shell bed [USB] is a major Typel shell bed. It is 12 meters thick and made up of at least three subsidary Type I shell beds (A, B and C in Figs. 12, 15). It also includes many interbedded simple shell beds. The base of the USB is gradational and rests on heterolithic, highly bioturbated muddy sandstones, massive sandy mudstones, and laminated mudstones from inner-shelf environments, with isolated and fragmented valves that gradually increase upwards. The USB exhibits an overall up-

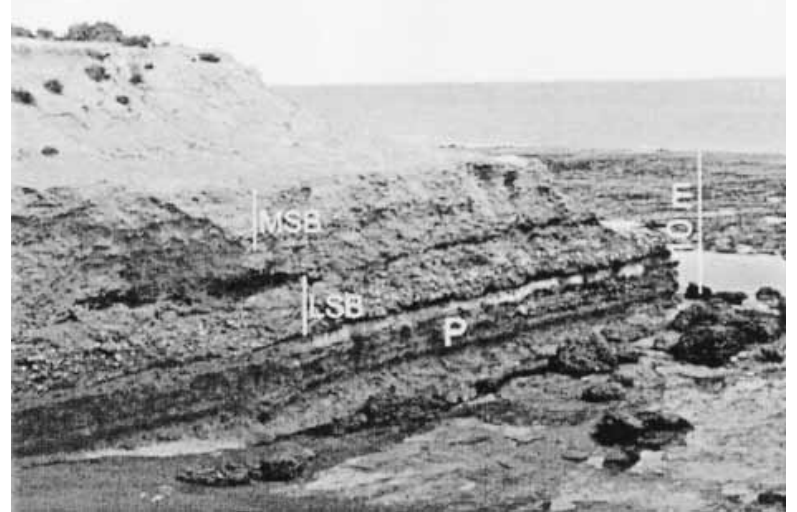

FIGURE 14-Lower Type IV shell bed (LSB) and Middle composite Type IV-I shell bed (MSB). P = "Patagonian" beds.

section increase in the stratigraphic close-spacing of simple shell-beds (increase in their degree of amalgamation, shell-packing, and the thickness of densely fossiliferous component intervals). The upper contact of the USB has been correlated over $35 \mathrm{~km}$ and is overlain by $13 \mathrm{~m}$ of laminated and highly bioturbated mudstone rich in radiolaria and diatoms and exhibiting the Cruziana Ichnofacies. These capping mudstones are especially well exposed in the Puerto Pirámide and Eje Tentativo areas (Fig.16), and record the maximum depth attained by the sea in the study area.

Each subsidary Type I shell bed within the USB grades upwards from a bioturbated muddy sandstone or sandy mudstone wherein shells are matrix-supported, to a less muddy shell-supported interval. Shells within matrixsupported intervals may be evenly dispersed or concentrated in thin single-event or multi-event shell beds. The single-event shell beds commonly represent census assemblages of Assemblages OS and AO, whereas the multievent ones are constituted by Assemblage $A O$ with erosive lower contacts and no internal discontinuities. Stratigraphy and taphonomic features of assemblages of the shellsupported and matrix-supported intervals of subsidary Type I shell beds are illustrated in Figure 12 and summarized in Table 2.

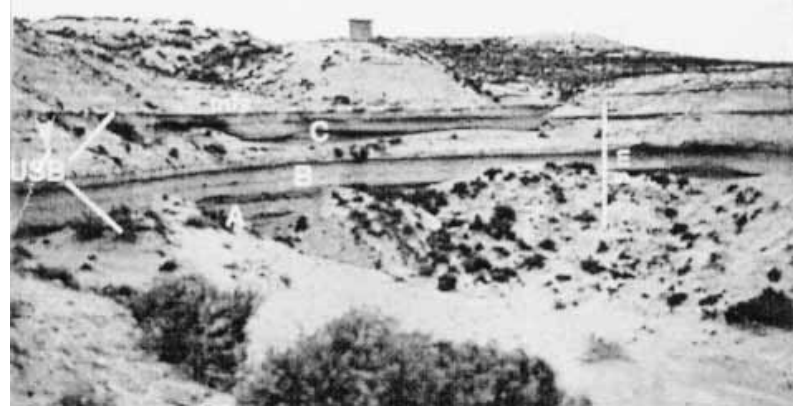

FIGURE 15-Major Type I, Upper shell beds at Eje Tentativo Ob, showing subsidary "A," "B," and "C" Type I shell beds. Overlying the maximum flooding surface (mfs) there are bioturbated and laminated mudstones recording the deepest depth attained by the Miocene sea. The mfs extends for $35 \mathrm{~km}$ and is recorded at the base of the section illustrated in Figure 16. 


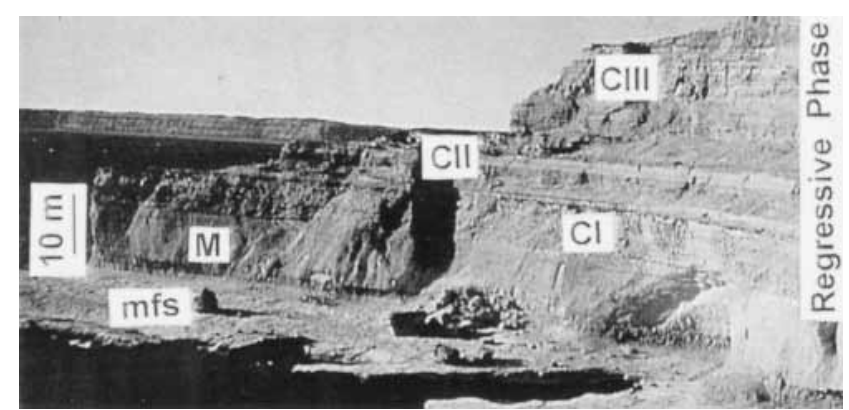

FIGURE 16-Regressive Phase of the Puerto Madryn Formation in Puerto Pirámide's area. mfs = maximum flooding surface. Overlying mudstones $(\mathrm{M})$ correspond to the deepest deposits recorded. $\mathrm{C}=$ upward-deepening sedimentary cycles represented by sandbars deposits. Prominent layers at the top of each cycle represent environmentally condensed shell beds that cap the sandbars.

\section{RegressivePhase}

The Regressive Phase consists of a 45-m-thick interval of intercalated gray and bluish massive or cross-stratified sandstones, whitish massive pyroclastic horizons, sandy or muddy heterolithic beds, and densely fossiliferous accumulations. One of the most conspicuous features of this

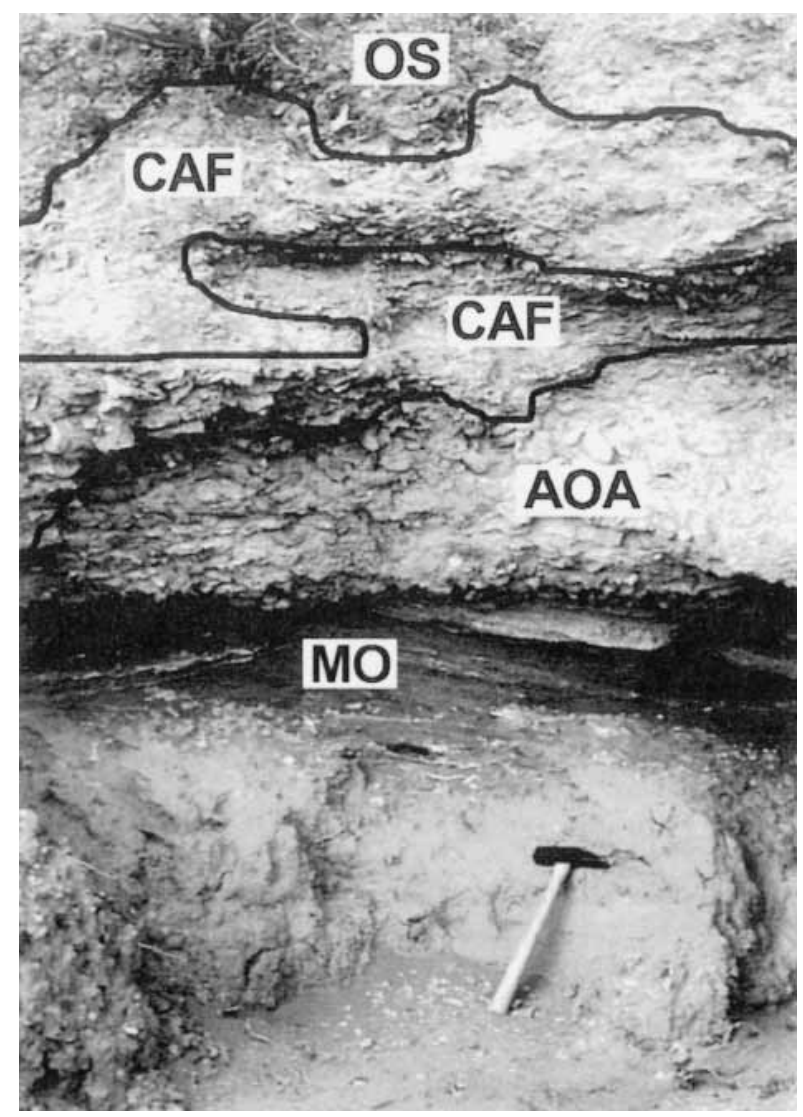

FIGURE 17-Environmentally condensed Type IV-I shell bed deposited in upper shoreface (MO: census assemblage of Monophoraster darwini and Ostrea patagonica), lower shoreface (Assemblage AOA), to inner-shelf environments (Assemblage CAF) capping upward-deepening Cycle I in Salina Grande. Shoreface sandbar deposits underlying the shell bed.

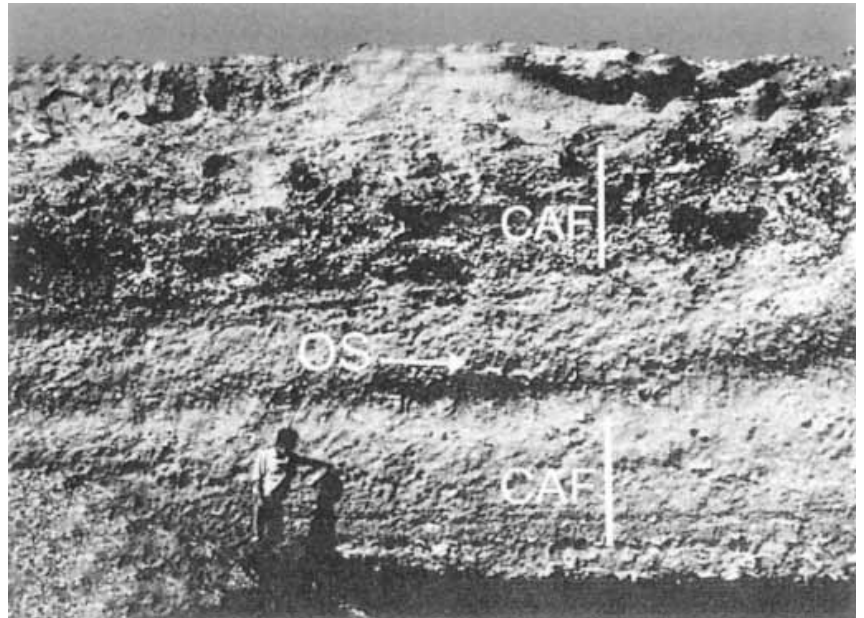

FIGURE 18-Exceptionally thick example of multi-event shell bed at the top of Cycle II at San José section.

phase is the development of large channels infilled with thin, single-event hardpart accumulations, and the presence of three sedimentary cycles $(\mathrm{Cl}, \mathrm{CII}$, and CIII in Figs. $3,16)$.

Lenticular sandstones, shell beds, and conglomerate bodies up to $6 \mathrm{~m}$ thick, persist laterally for hundreds of meters in outcrops and have strongly erosive lower and planar upper contacts. Sandy shell beds are cross-stratified and contain allochthonous, multi-event, shell-supported accumulations. They represent largetidal-channel deposits and yield Assemblage OMA, OS, and MZ. Accumulations mainly consist of shell hash or highly fragmented and abraded valves of pectinids, oysters, veneroids, gastropods, bryozoan colonies, and tests of Monophoraster, but accumulations composed exclusively of entireand disarticulated valves of oysters are also common.

Each of the three sedimentary cycles is composed of up to $15 \mathrm{~m}$ of heterolithic deposits or massive bioturbated muddy or sandy strata (Fig. 12). Thin, time-averaged accumulations of Assemblage MO, AO, and MOT, as well as census concentrations of Cyrtopleura lanceol ata in life position, are recorded from these heterolithic strata, which are otherwise barren. The upper part of each cycle is bioturbated and the top is a strongly bioturbated surface dominated by Skolithos and Ophiomorpha that can be correlated over $30 \mathrm{~km}$. Beneath each of these surfaces, in $\mathrm{Cl}$ and $\mathrm{CII}$, and sometimes disrupted by bioturbators, is a thin census assemblage of Monophoraster darwini in life position (Assemblage MO). Each bioturbated surface is overlain by a 0.3-to-0.8-m-thick, multi-event, strongly amalgamated and shell-supported (30\% sedimentary matrix) Type IV-I shell bed (Fig.17). These havelower erosive and upper planar contacts and yield Assemblage AOA and CAF, and less frequently Assemblage OMA. Each of these shell-beds is capped by a pavement of Assemblage GROT, although pavements of Dosinia meridionalis or Monophoraster darwini are frequent in the Punta Pirámide and San J osé sections. An exceptionally thick, multi-event and slightly amalgamated shell bed caps the Cycle II at the San J osé section (Fig. 18). 


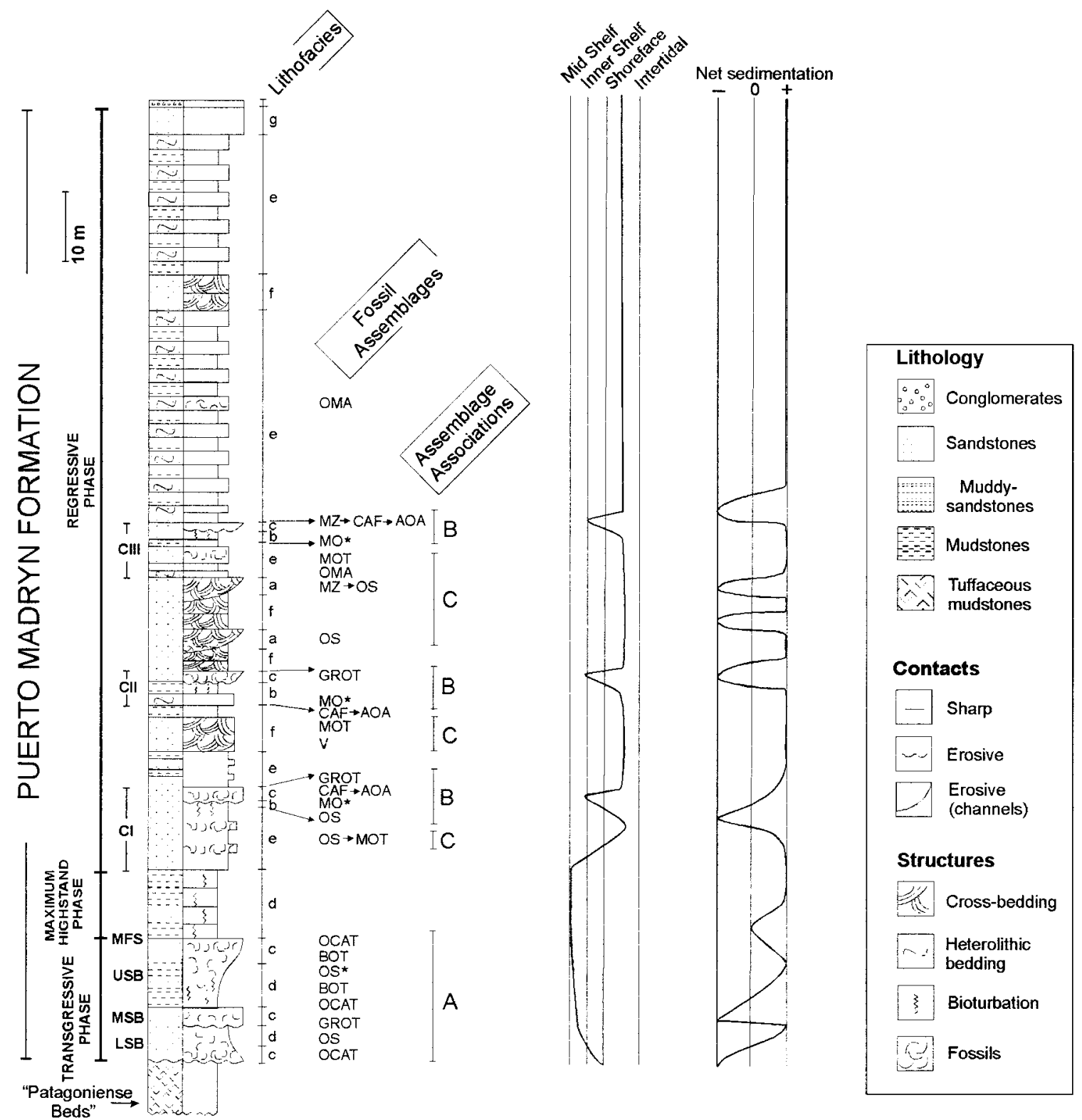

FIGURE 19-Record of water depth deposition and changes in net sedimentation of the Miocene sequence related to lithofacies and fossil assemblages. Lithofacies code as in Figure 2; Association A recovered from storm shell beds, deposited in mid-and inner- shelf environments (autochthonous time-averaged assemblages); Association B recovered from the top of shoreface sandbars; records deepening in water-depth from upper shoreface settings to lower shoreface and inner shelf environments (census assemblages and environmentally condensed shellbeds); Association C recovered from upper shoreface tidal channels (census and allochthonous assemblages).

\section{History of Dynamic Accumulation}

The contact of the Lower shell bed with the "Patagoniense" beds is considered a coplanar transgressive-ravine ment and subaerial unconformity surface (Scasso et al., 1999b). In measured sections, to the west and southwest, the characteristics of the Lower shell-bed match that of a lag-concentration coquina of Banerjee and Kidwell (1991), showing laterally discrete lens geometry and evidence of exhumation and shoreface erosion. Dense hardpart concentrations that characterize the Lower and Middle shell beds mostly correspond to within-habitat, time-averaged assemblages accumulated under omission conditions. Taphonomic features, including the internal stratigraphy of the shell beds, indicate omission was caused by conditions of dynamic bypass with alternating periods of deposition and erosional events, promoted by frequent stormwave reworking and strong tidal currents. The presence of minor internal discontinuities, relative abundance of shell-gravel taxa, considerable high post-mortem damage of valves by encruster and borer epibionts, disarticulation of shells, lack of size, and right/left valve sorting, and low degree of fragmentation all point to a concentration of indigenous taxa of successive assemblages that might have been exposed on the seafloor during ecol ogically prolonged periods of non-deposition. Omission conditions were probably interrupted by short aggradational intervals that entombed shell-gravel taxa and all owed colonization by soft- 
bottom shallow and deep burrowers (Dosi nia meridional is and Panopea regularis among others). Erosional deep reworking events and winnowing of sedimentary matrix amalgamated a mosaic of different assemblages indigenous to the area, leading to a vertical admixture of shellgravel and soft-bottom dwellers and to densely packed shell beds with internal discontinuities. Owing to the high percentage of articulated shells of Glycymerita magna and Eurhomalea ninfasiensis, depositional events might have been rapid, causing an immediate burial of shells. Otherwise, those taxa should have disarticulated rapidly in these areas strongly swept by tidal currents.

The U pper shell bed, situated immediately bel ow Maximum Highstand deposits, reflects lower-energy conditions characterized by alternating aggradation and omission (Pathway 2 of Kidwell and J ablonski, 1983). The highly bioturbated muddy sandstone intervals accumulated during dominant depositional intervals, which were interrupted by brief omissional intervals during which thin census and thicker multi-event Assemblages AO and OS accumulated. Taphonomic features of census assemblages reflect no evidence of post-mortem infestation and suggest only brief periods of post-mortem residence on the seafloor and rapid burial that isolated the assemblage from subsequent bioturbation or hydraulic reworking. Multi-event accumulations suggest alternation of brief periods of deposition and longer intervals of non-deposition that allowed repeated colonization of the soft-bottom reclining Ostrea sp. and Amusi um paris assemblage. Weak hydraulic events winnowed the matrix but accomplished little movement or disarticulation of Amusium.

Based upon data, a gradual upwards change from aggradation to predominantly non-deposition is believed to bethe responsible for the generation of the densely packed parautochthonous-autochthonous multi-event accumulations at the top of each subsidary Type I shell bed within the Upper shell-bed. Omission intervals aremorefrequent and more prolonged towards the top of the main complex shell bed. It is suggested that omission was caused by complete bypassing and sediment starvation, based on the absence of internal discontinuity surfaces, low degree and local absence of amalgamation, lack of vertical admixture of successive assemblages, dominance of shell-gravel taxa, complete absence of soft-bottom burrowers, well-preserved ornamentation but total disarticulation of shells, and the high degree of post-mortem infestation by borers and especially by encrusting bryozoan colonies (Membranipora sp. on turritellids).

During accumulation of the Transgressive and Maximum Highstand phases, the paleogeography of the area probably was open to the Atlantic Ocean. Although these deposits represents the greatest water depths for the entire formation (mudstones bel ow storm-wave base), depositional environments largely remained in an inner-shelf affected by strong tides, as well as by fairweather and storm waves. Recorded assemblages inhabited firm gravel or sandy substrata in areas swept by strong currents, probably situated laterally or distally tothemouth of large tidal channels, in inner-to-mid-shelf environments, above the storm-wave base. Sand ridges and shoals reworked during a transgression by tidal currents or waves (Rine et al., 1986; Penland et al., 1986) can be modern environmen- tal analogues for the accumulation of this part of the section.

Agraddational intervals represented by scarcely disturbed hardparts or simple census shell- beds, as well as sedimentary matrix of fossil accumulations at the top of each subsidary Type I sell.beds, record deposition in lower energy and deeper enviroments towards the top of this lowest section. High rates of transgression with rapid deepening and/or reworking of shelf deposits into sand ridges reflect an accomodation/supply ratio $>1$ (e.g., Swift et al., 1991).

Deposition of the Regressive Phase was strongly influenced by tidal regimes and it reflects a more closed environment. According to paleocurrent data (Scasso and del Río, 1987), sediment transport was mainly along a large embayment oriented NE-SW. The fauna indicates normal marine conditions, and no definitive evidence of brackish or fresh water (fluvial) deposits have been found in the Península Valdés area, although important channel incision is evident to the southwest. Cross-bedded sandstones, together with gravel and broken-shell coquina lags, are frequent there and were interpreted as the deposits of largetidal channels (Scasso and del Río, 1987). At the SW part of the embayment they are associated with stacked sets of inclined heterolithic stratification, which are typical of estuarineincised channels (e.g., Eberth, 1996).

To the NE, the heterolithic deposits of the Regressive Phase are intercalated with mud-draped cross-bedded sands and shell beds and constitute Cycles I, II, and III. These deposits are interpreted to be tidal bars and "sand tongues" (fan-shaped sandbars that run parallel to tidal channels and normal to the coast similar to those described in Nordergründe area, southward of the Elbe estuary-see Reineck and Singh, 1980) deposited in environments alternately dominated by tidal currents or waves. Wave action is evident in the form of wave-ripple bedding within heterolithic beds, and bioturbation is low (compare with Davis and Flemming, 1995). These sand bodies are often capped by shell-rich beds (cf. Hertweck, 1998). During formation of sandbars, short omission events are inferred due to the presence of census Assemblages $\mathrm{MO}$, or by single-event, time-averaged concentrations of Assemblage AO, after which of deposition suddenly resumed. The top of sandbars record a definite change from positive values of net sedimentation towards dominant omission conditions. Bar tops are defined by the last accumulation of Monophoraster darwini in life position in highly turbulent environment, placed very close to the breaker zone. A short and catastophic depositional event, probably promoted by storms, accumulated a thick sedimentary increment leading to sudden entombment of the echinoids. Following the burial of this community, omission conditions are indicated by the activity of soft bottomdwellers that bi oturbated the entombing sediment resulting in Skolithos and Ophiomorpha ichnofabrics. Subsequent deepening and prolonged omission are recorded. Once appropriate depths were attained, Amusium paris, Flabellipecten piramidesensis, and Aequi pecten paranensis colonized shoreface soft-sandy bottoms, situated close to fairweather wave base and often swept by weak currents or waves. Continuous deepening allowed the settlement of $C$. actinodes in lower inner shelf gravel-substrata swept by strong tidal currents, situated well below wave 
base. Omissional phases often were interrupted by deposition of thick increments of sediments that allowed deep and shallow infaunal soft-bottom dwellers to colonize the seafloor. Occasionally, strong erosional storm events promoted amal gamation and vertical admixture of successive soft and gravel-substrata assemblages, as well as the winnowing of matrix leading to strongly amalgamated shell beds. However, this reworking apparently was limited in effect, because most of the deep burrowers are preserved articulated.

Each of the cycles records an upwards deepening from restricted upper shoreface (sandbars) to inner-shelf environments. The complex Type IV-I shell beds that cap each cycle appear to be environmentally condensed accumulations that represent flooding surfaces and prolongedphases of non-deposition. Whether these water-depth fluctuations were caused by autocyclic (channel and sand tongue lateral shifting) or allocyclic (sea-level fluctuations) mechanisms remains uncertain, but the general style of accumulation is regressive-progradational, probably with expanded offlapping parasequences (sensu E mbry, 1995) reflecting accomodation/supply ratio $<<<1$.

Figure 19 summarizes the history of the accumulation of the sequence, the environmental variation during deposition, and the resulting changes in living benthic faunas represented by the fossil assemblages.

\section{ACKNOWLEDGMENTS}

We acknowledge with thanks to S. Kidwell (University of Chicago) for her corrections and suggestions on the manuscript, as well as for her improvement of the English text. We also greatly appreciate comments and ecological data provided by R. Mooi (California Academy of Science), R. Thomas (Franklin and Marshall College), T. Waller (Smithsonian Institute, National Museum of Natural History), Lopez Gappa (Museo Argentino de Ciencias Naturales "Bernardino Rivadavia"), and H. Zaixo (Universidad Nacional del Sur). This paper was supported by Research Projects PEI 944/97 and PID 3327700/92-96 (Consejo Nacional de Investigaciones Científicas y Técnicas, Argentina), by the Comisión Sectorial de Investigación Científica de la Universidad de la República (Uruguay) and the Universidad de Buenos Aires (UBACYT EX299 and TW168 projects). The editorial office of PALAIOS is thanked for their assistance with revision of the manuscript.

\section{REFERENCES}

АввотT, R.T., and DANCE, S.R., 1986, Compendium of Seashells: American Malacologists, I nc., Florida, $411 \mathrm{p}$.

BANERJ E, I., and KIDWELL, S.M., 1991, Significance of molluscan shell beds in sequence stratigraphy: An example form the Lower Cre taceous Mannville Group of Canada: Sedimentology, v. 38, p. 913934.

BernasConi, M.P., and RobBA, E., 1993, Molluscan paleoecology and sedimentogical features: An integrated approach from the Miocene Meduna section, northern I taly: Palaeogeography, Palaeoclimatology, Palaeoecology, v. 100, p. 267-290.

CIONE, A.L., 1978, Aportes paleoictiológicos al conocimiento de la evolución de las paleotemperaturas en el área austral de América del Sur durante el Cenozoico. Aspectos zoogeográficos conexos: Ameghiniana, v. 15, p 183-208.

CiOnE, A.L., 1988, Los peces de las formaciones marinas del Cenozo- ico de Patagonia: Unpublished Tesis de Doctorado, Universidad de la Plata, Argentina, $536 \mathrm{p}$.

CIONE, A.L., and TONNI, E.P., 1981, Un pingüino de la Formación Puerto Madryn (Mioceno tardío) de Chubut, Argentina. Comentarios acerca del orígen, paleoecología y la zoogeografía de los Spheniscidae: 2 Congreso Latinoamericano de Pal eontología, Anais, p. 591-604.

CozzUOL, M.A., TAMBussı, and NoRIEgA, J ., 1993, Un pingüino(Aves: Spheniscidae) dela Formación Puerto Madryn (Miocenomedio) en P. Valdés, Chubut. Argentina, con importantes implicancias filogenéticas: 10 o J ornadas Argentinas de Paleontol ogía de Vertebrados, La Plata, (12-15 mayo, 1993), Ameghiniana, v. 30, p. 327

CHINZEI, K., 1995, Adaptive significance of the ligthweight shell structure in soft bottom oysters: Neues] ahrbuch für Geol ogieund Paläeontologie, v. 195, p. 2217-227.

DAVIS, R.A., J R., and FLEMMING, B.W., 1995, Stratigraphy of a combined wave and tide-dominated intertidal sand body: Martens Plate, East Frisian Wadden Sea, Germany: in FLEMMING, V.W., and BARTHOLOMÄ, A., eds., Tidal Signatures in modern and ancient sediments: International Association of Sedimentologists, Special Publication no. 24, p. 121-132.

DEL Río, C.J ., 1988, Bioestratigrafía y Cronoestratigrafía de la Formación Puerto Madryn (Mioceno medio). Provincia del ChubutArgentina: Academia Nacional de Ciencias Exactas, Físicas y $\mathrm{Na}$ turales de Buenos Aires, Anales, v. 40, p. 231-254.

DEL Río, C.J ., 1989, Bioestratigrafía y Paleontología de los Bivalvos y Gastropodos de la Formación Puerto Madryn (Mioceno medio marino) de península Valdés y alrededores de Puerto Madryn, Provincia del Chubut: Unpublished Tesis de Doctorado en Ciencias Geológicas, Universidad de Buenos Aires, Argentina, 672 p.

DEL Río, C.J ., 1992, Middle Miocene bivalves of the Puerto Madryn Formation, Valdés Peninsule, Chubut Province, Argentina (Nuculidae-Pectinidae), Part I: Palaeontographica, Abteilung A, no. 225, p. 1-57.

DEL Río, C.J ., 1994, Middle Miocene bivalves of the Puerto Madryn Formation, Valdés Peninsule, Chubut Province, Argentina (Lucinidae-Pholadidae), Part II: Palaeontographica, Abteilung A, no. 231, p. 93-132.

DEL Río, C.j ., in press, El Mioceno medio-tardío marino de la República Argentina. Análisis de su Malacofauna: Serie de Correlación Geológica.

DEL Río, C.J ., and MARTínez, S.A. 1998a, El Mioceno marino en la Argentina y en el Uruguay: in DEL RÍo, C.J ., ed., Moluscos marinos Miocenos de la Argentina y del Uruguay: Academia Nacional de Ciencias Exáctas Físicas y Naturales, Buenos Aires, Monografía 15, p. 6-25

DEL Río, C.J ., AND MARTínez, S.A., 1998b, Clase Bivalvia: in DEL Río, C.J ., ed., Moluscos marinos Miocenos de la Argentina y del Uruguay: Academia Nacional de Ciencias Exáctas Físicas y Naturales, Buenos Aires, Monografía 15, p. 48-83.

Dozo, M.T., Vucetich, M.G., MontI, A., AND BouzA, P., 1999, Vertebrados continentales en la Formación Puerto Madryn (Mioceno superior) en península Valdés (Chubut, Argentina): $14^{\circ}$ J ornadas Argentinas de Paleontología de Vertebrados. (Neuquen, 1998), Ameghiniana, v. 36, p. 99 .

EвERTH, D.A., 1996, Origin and significance of mud-filled incised valleys (Upper Cretaceous) in southern Alberta, Canada: Sedimentology, v. 43, p. 459-477.

EMBRY, A.F., 1995, Sequence boundaries and hierarchies: problems and proposals: in STEEL, R.J., FELT, V.L.,J OHANNESSEN, E.P., AND MATTHIEW, C., eds., Sequence-stratigraphy on the Northwest European Margin: Norsk Petroleumsforening Special Publication No. 5: Elsevier, Amsterdam, p. 1-11.

Escofet, A.M., Oresanz, J.M., Olivier, S.R., and Scaravino, V., 1978, Biocenología Bentónica del Gol foSan Matías (RíoNegro, Argentina): Metodología, experiencias y resultados del estudio ecológico de un gran espacio geográfico en América Latina: Centro de Ciencias del Mar y Limnología. Universidad Nacional Autónoma de México, Anales v. 5, No. 1, p. 59-82.

HALLER, M., 1978, Estratigrafía de la región al poniente de Puerto Madryn: $2^{\circ}$ Congreso Geológico Argentino, Actas, v. 1, p. 285-297. HEALD, D.Y., AND CAPUTI, N., 1981, Some aspects of growth, recruitment and reproduction in the southern Saucer Scallop, Amusium 
balloti (Bernardi, 1861) in Shark Bay, Western Australia: Fisheries Research, Bulletin no. 25, p. 1-33.

HERTWECK, G., 1998, Facies characteristics of back-barrier tidal flats of the east Frisian Island of Spiekeroog, southern North Sea: in Alexander, C.R., Davis, R.A., AND HenRY, V.J ., eds., Tidalites: Processes and products: Society of Economic Pal eontologists and Mineralogists, Special Publication No. 61, p. 23-30.

Holmes, N.A., 1966, The bottom fauna of the English Channel. Part 2: J ournal of Marine Biology Association U.K., v. 46, p. 401-493.

J OHNSON, H.D., AND BALDWIN, C.T., 1996, Shallow clastic seas: in READING, H.G., ed., Sedimentary Environments, Processes, Facies and Stratigraphy: Blackwell Scientific Publication, Oxford, p. 232-280.

J OLL, L.M., 1988, Recruitment variation in stocks of the saucer scalIop Amusium balloti in the Abrolhos Islands area: in DREDGE, M.C.L., ZACHARIN, W.F., AND J OLL, L.M., eds., Proceedings of the Australian Scallop Workshop: Hobart, Australia, p. 61-67.

J OLL, L.M., 1989, Swimming behaviour of the saucer scallop Amusium balloti (Mollusca: Pectinidea): Marine Biology, v. 102, p. 299-305.

KIDWELL, S.M., 1986, Models for fossil concentrations: Paleobiologic implications: Paleobiology, v. 12, p. 6-24.

KIDWELL, S.M., 1991, The stratigraphy of Shell Concentrations: in Allison, P.A., AND BRIGGS, D.E.G. eds., Taphonomy: Releasing the Data Locked in the Fossil Record: Topics in Geobiology, v. 9, p. 211-290.

KIDWELL, S.M., AND J ABLONSKI, D., 1983, Taphonomic feedback. Ecological consequences of shell accumulation: in TEVESZ, M.J.S., AND MCCALL, P.L., eds., Biotic Interactions in Recent and Fossil Benthic Communities: Plenum Press, New York, p. 195-248.

LEVELL, B.K., 1980, A late Precambrian tidal shelf deposit, the Lower Sanjfjord Formation, Finnmark, North Norway: Sedimentology 27, p. 153-166.

LEVINGTON, J .S., 1970, The pal eoecological significance of opportunistic species: Lethaia, v. 3, p. 69-78.

MartíneZ, S.A., DEL Río, C.J ., AND Reichler, V., 1998, ClaseGastropoda: in DEL Río, C.J ., ed., Moluscos marinos Miocenos de la Argentina y del Uruguay: Academia Nacional de Ciencias Exáctas Físicas y Naturales, Buenos Aires, Monografía 15, p. 26-47.

MoOI, R., MARTíneZ, S., AND PARMA, S.G., 2000, Phylogeneticsystematics of Tertiary Monophorasterid sand dollars (Clypeasteroida: Echinoidea) from South America: J ournal of Paleontol ogy, v. 74, p. 263-281.

Olivier, S.R., Kreibhom de PAternoster, I., AND BAstida, R., 1966, Estudio biocenótico en las costas de Chubut (Argentina) I. Zonación biocenológica de Puerto Pardelas (Golfo Nuevo): Instituto de Biología Marina, Boletín No. 10, p. 1-71.

Penland, S., Suter, J .R., Moslov, T.F., 1986, Inner shelf shoal sedimentary facies and sequences: Ship Shoal, northern Gulf of Mexico: in MOSLOV, T.F., AND RHODES, E.G., eds., Modern and ancient shelf clastics: Society of Economic Paleontologists and Mineralogists, Core Workshop no. 9, p. 73-123.

REINECK, H.E., AND SIGH, I.B., 1980, Depositional sedimentary envi- ronments with References to Terrigenous Clastics: Springer-Verlag, Berlin, $542 \mathrm{p}$

Rine, J.M., TILLMAN, R.W., Stubblefield, W.L., AND SWift, D.J .P., 1986, Lithostratigraphy of Holocene sand ridges from the nearshore and middle continental shelf of New J ersey, U.S.A.: in MosLOV, T.F., AND RHODES, E.G., eds., Modern and ancient shelf clastics: Society of Economic Paleontologists and Mineralogists, Core Workshop no. 9, p. 1-72.

Rıva Rossı, C.M., 1996, Una nueva especiedel género Genypterus (Pisces, Ophidiiformes) del Mioceno medio de Península Valdés (Chubut) y sus relaciones filogenéticas con los abadejos actuales: $12^{\circ} \mathrm{J}$ ornadas Argentinas de Paleontología de Vertebrados, La Pampa, Resúmenes, p. 68.

SCASSO, R., AND DEL Río, C.J ., 1987, Ambientes de sedimentación y proveniencia de la secuencia marina del Terciario Superior de la región de península Valdés: Revista dela Asociación Geológica Argentina, v. 42, p. 291-321.

Scasso, R., Del Río, C.J., MacArthur, J.M., ANd Martínez, S., 1999a, Edades ${ }^{87} \mathrm{Sr} /{ }^{16} \mathrm{Sr}$ para el Entrerriense (Mioceno) de península Valdés, provincia del Chubut, Argentina: $14^{\circ}$ Congreso Geológico Argentino, Resúmenes, p. 73.

SCASSO, R., DEL RíO, C.J ., AND MARTínEZ, S., 1999b, El contacto “Entrerriense"-_"Patagoniense" en península Valdés: Examen deuna discontinuidad: $14^{\circ}$ Congreso Geológico Argentino, Resúmenes, p. 73.

SEILACHER, A., 1984, Constructional morphology of Bivalves: Evolutionary pathways in primary versus secondary soft-bottoms dwellers: Palaeontology, v. 27, p. 207-237.

Sprechmann, P., Verde, M., Martinez S, and GauCHer, C, 1998 Paleoecología y ambientes de sedimentación de Biostromos y "patch reefs" de ostreidos, sus endolitos y epibiontes (Formación Camacho, Mioceno medio-superior; Uruguay): Actas $2^{\circ}$ Congreso Uruguayo de Geología, p. 205-209.

SWIFT, D.J .P., PHILliPS, S., AND ThORNE, J .A., 1991, Sedimentation on continental margins, V: Parasequences: in SWIFT, D.J .P., OERTEL, G.F., TILLMAN, R.W., AND THORNE, J .A., eds., Shelf sand and sandstone bodies: Geometry, facies and sequencestratigraphy: International Association of Seidmentologists, Special Publication no. 8, p. 369-392.

THOMAS, R.D., 1975, Functional morphology, ecology and evolutionary conservatism in the Glycymeridae (Bivalvia): Palaeontology, v. 18, p. 217-254.

Villaverde, L.M., Mestre, F., Gimenez, O., and Turturro de MesTRE, 1974, La exploración e Investigación submarina en el Golfo Nuevo: Instituto Argentino de Oceanografía CIESGON, Contribución Científica, No. 14, p. 1-57.

ZAIXO, H., 1975, Distribución vertical de los moluscos marinos de la Ría Deseado (Santa Cruz, Argentina) sustratos con fracción limosa: Physis, v. 34, p. 229-243.

ZAIXO, L., 1996, Distribución de Chlamys tehuelcha y Chlamys patagonica (Bivalvia, Pectinidae) en el golfo San J osé (Chubut, Argentina) en función de la profundidad y del sustrato: Physis, sección A, No. 51 (120-121), p. 1-11.

ACCEPTED OCTOBER 10, 2000 
APPENDIX 1

Relative abundance of species composition of the study shell-beds of the Miocene Puerto Madryn Formation. $\mathrm{D}=\mathrm{Dominant}(>50 \%$ ) $\mathrm{A}=$ abundant (25\%-50\%); C = common (25-5\%); $\mathrm{R}=$ rare ( $<5 \%)$. (A1,C3b $=$ stratigraphic beds in sections as illustrated in Figure 3 )

RELATIVE ABUNDANCE OF SPECIES

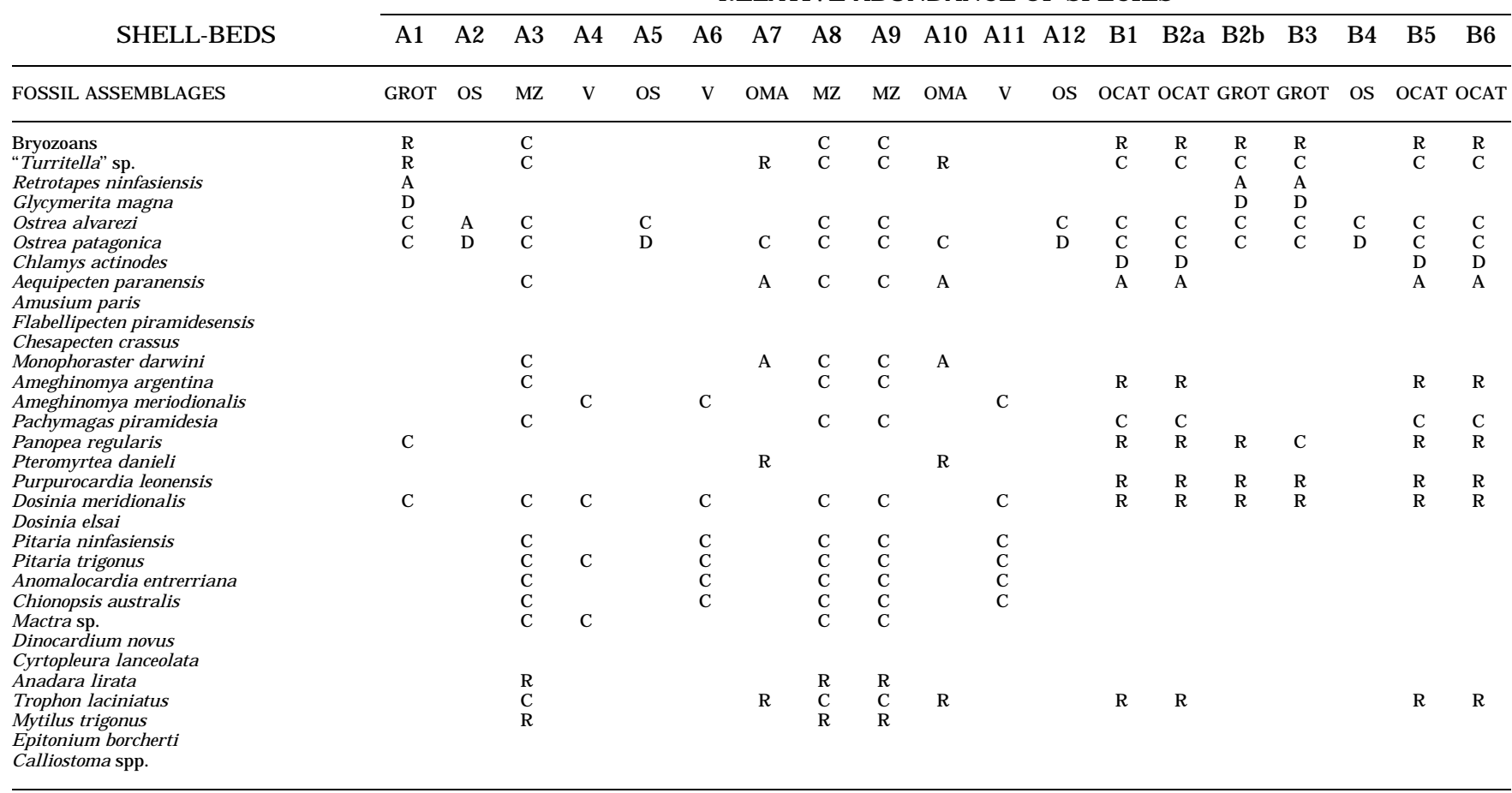

APPENDIX 1

Continued.

RELATIVE ABUNDANCE OF SPECIES

$\begin{array}{lllllllllllllllllllllll}\text { SHELL-BEDS } & \text { B7 } & \text { B8 } & \text { B9 } & \text { B10 } & \text { B11 } & \text { B12 } & \text { B13 } & \text { B14 } & \text { B15 } & \text { B16 } & \text { B17 } & \text { B18 B19 } & \text { B20 } & \text { B21 } & \text { C1a } & \text { C1b } & \text { C2 } & \text { C3a }\end{array}$ FOSSIL ASSEMBLAGES OCAT GROT GROT MO OS OS GROT MO MO OMA OMA MO OMA OMA GROT OS GROT BOT OCAT

\begin{tabular}{|c|c|c|c|c|c|c|c|c|c|c|c|c|c|c|c|c|c|c|c|}
\hline Bryozoans & $\mathrm{R}$ & $\mathrm{R}$ & $\mathrm{R}$ & & & & $\mathrm{R}$ & & & & & & & & & & $R$ & $D$ & $\mathrm{R}$ \\
\hline “Turritela” sp. & C & C & c & & & & C & & & $\mathrm{R}$ & $\mathrm{R}$ & & $\mathrm{R}$ & $\mathrm{R}$ & & & C & A & C \\
\hline Retrotapes ninfasiensis & & A & A & & & & A & & & & & & & & $\mathrm{R}$ & & A & & \\
\hline Glycymerita magna & & D & D & & & & D & & & & & & & & D & & D & & \\
\hline Ostrea alvarezi & C & C & C & & C & C & $\mathrm{C}$ & & & & & & & & & C & C & C & C \\
\hline Ostrea patagonica & $\mathrm{c}$ & C & C & D & $\mathrm{D}$ & D & $\mathrm{C}$ & D & D & C & C & D & C & C & & D & c & $\mathrm{R}$ & C \\
\hline Chlamys actinodes & D & & & & & & & & & & & & & & & & & & $\mathrm{D}$ \\
\hline Aequipecten paranensis & A & & & & & & & & & A & A & & A & A & & & & & A \\
\hline \multirow{2}{*}{\multicolumn{20}{|c|}{$\begin{array}{l}\text { Amusium paris } \\
\text { Flabellipecten piramidesensis }\end{array}$}} \\
\hline & & & & & & & & & & & & & & & & & & & \\
\hline Chesapecten crassus & & & & & & & & D & D & & & & & & & & & & \\
\hline Monophoraster darwini & & & & D & & & & & & A & A & D & A & A & & & & & \\
\hline Ameghinomya argentina & $\mathrm{R}$ & & & & & & & & & & & & & & & & & & $\mathrm{R}$ \\
\hline \multicolumn{20}{|l|}{ Ameghinomya meridionalis } \\
\hline Pachymagas piramidesia & C & & & & & & & & & & & & & & & & & & C \\
\hline Panopea regularis & $\mathrm{R}$ & $\mathrm{R}$ & $\mathrm{R}$ & & & & $\mathrm{R}$ & & & & & & & & C & & $\mathrm{R}$ & & $\mathrm{R}$ \\
\hline Pteromyrtea danieli & & & & & & & & & & $\mathrm{R}$ & $\mathrm{R}$ & & $\mathrm{R}$ & $\mathrm{R}$ & & & & & \\
\hline Purpurocardia leonensis & $\mathrm{R}$ & $\mathrm{R}$ & $\mathrm{R}$ & & & & $\mathrm{R}$ & & & & & & & & C & & $\mathrm{R}$ & & $\mathrm{R}$ \\
\hline Dosinia meriodionalis & $\mathrm{R}$ & $\mathrm{R}$ & $\mathrm{R}$ & & & & $\mathrm{R}$ & & & & & & & & C & & $\mathrm{R}$ & & $\mathrm{R}$ \\
\hline \multirow{2}{*}{\multicolumn{20}{|c|}{$\begin{array}{l}\text { Dosinia elsai } \\
\text { Pitaria ninfasiensis }\end{array}$}} \\
\hline & & & & & & & & & & & & & & & & & & & \\
\hline \multicolumn{20}{|l|}{ Pitaria trigonus } \\
\hline \multicolumn{20}{|l|}{ Anomalocardia entrerriana } \\
\hline \multicolumn{20}{|l|}{ Chionopsis australis } \\
\hline \multicolumn{20}{|l|}{ Mactra sp. } \\
\hline \multicolumn{20}{|l|}{ Dinocardium novus } \\
\hline \multirow{2}{*}{\multicolumn{20}{|c|}{$\begin{array}{l}\text { Cyrtopleura lanceol ata } \\
\text { Anadara lirata }\end{array}$}} \\
\hline & & & & & & & & & & & & & & & & & & & \\
\hline Trophon Iaciniatus & $\mathrm{R}$ & & & & & & & & & $\mathrm{R}$ & $\mathrm{R}$ & & $\mathrm{R}$ & $\mathrm{R}$ & & & & & $\mathrm{R}$ \\
\hline \multirow{2}{*}{\multicolumn{20}{|c|}{$\begin{array}{l}\text { Mytilus trigonus } \\
\text { Epitonium borcherti }\end{array}$}} \\
\hline & & & & & & & & & & & & & & & & & & & \\
\hline Calliostoma spp. & & & & & & & & & & & & & & & & & & & \\
\hline
\end{tabular}


APPENDIX 1

Continued.

\begin{tabular}{|c|c|c|c|c|c|c|c|c|c|c|c|c|c|c|c|c|c|c|c|}
\hline \multirow[b]{2}{*}{ SHELL-BEDS } & \multicolumn{19}{|c|}{ RELATIVE ABUNDANCE OF SPECIES } \\
\hline & $\mathrm{C} 3 \mathrm{~b}$ & C5 & $\mathrm{C} 6$ & $\mathrm{C7}$ & C8 & C9 & D1 & D2 & D3 & D4 & D5 & D6 & D7 & E1 & E2 & E3 & E4 & E5 & E6 \\
\hline FOSSIL ASSEMBLAGES & OCAT & ВОТ & GROT & MOT & MOT & $M Z$ & ВОт & OCAT & BOT & OCAT & OCAT & OCAT & OCAT & BOT & OCAT & OCAT & GROT & ВОт & OCAT \\
\hline Bryozoans & $\mathrm{R}$ & D & $\mathrm{R}$ & & & C & D & $\mathrm{R}$ & D & $\mathrm{R}$ & $\mathrm{R}$ & $\mathrm{R}$ & $\mathrm{R}$ & D & $\mathrm{R}$ & $\mathrm{R}$ & & D & $\mathrm{R}$ \\
\hline “Turritella” sp. & C & A & C & $\mathrm{R}$ & $\mathrm{R}$ & $\mathrm{C}$ & A & C & A & C & C & C & C & A & C & $\mathrm{C}$ & & A & C \\
\hline Retrotapes ninfasiensis & & & A & & & & & & & & & & & & & & C & & \\
\hline Glycymerita magna & & & D & & & & & & & & & & & & & & $\mathrm{D}$ & & \\
\hline Ostrea alvarezi & C & C & C & D & D & C & C & C & C & C & C & C & C & C & C & C & & C & C \\
\hline Ostrea patagonica & C & $\mathrm{R}$ & C & & & $\mathrm{C}$ & $\mathrm{R}$ & C & $\mathrm{R}$ & C & $\mathrm{C}$ & C & $\mathrm{C}$ & $\mathrm{R}$ & $\mathrm{C}$ & $\mathrm{C}$ & & $\mathrm{R}$ & C \\
\hline Chlamys actinodes & D & & & & & & & D & & D & D & D & D & & D & D & & & D \\
\hline Aequipecten paranensis & A & & & $\mathrm{R}$ & $\mathrm{R}$ & C & & A & & A & A & A & A & & A & A & & & A \\
\hline \multirow{2}{*}{\multicolumn{20}{|c|}{$\begin{array}{l}\text { Amusium paris } \\
\text { Flabellipecten piramidesensis }\end{array}$}} \\
\hline & & & & & & & & & & & & & & & & & & & \\
\hline \multirow{2}{*}{\multicolumn{20}{|c|}{ Chesapecten crassus }} \\
\hline Monophoraster darwini & & & & $\mathrm{R}$ & $\mathrm{R}$ & C & & & & & & & & & & & & & \\
\hline $\begin{array}{l}\text { Ameghinomya argentina } \\
\text { Ameghinomya meridionalis }\end{array}$ & $\mathrm{R}$ & & & & & C & & $\mathrm{R}$ & & $\mathrm{R}$ & $\mathrm{R}$ & $\mathrm{R}$ & $\mathrm{R}$ & & $\mathrm{R}$ & $\mathrm{R}$ & & & $\mathrm{R}$ \\
\hline $\begin{array}{l}\text { Ameghinomya meridionalis } \\
\text { Pachymagas piramidesia }\end{array}$ & C & & & & & $c$ & & $c$ & & $c$ & $c$ & $C$ & $C$ & & $C$ & $C$ & & & $c$ \\
\hline \multirow{2}{*}{\multicolumn{20}{|c|}{ Pteromyrtea danieli }} \\
\hline & & & & & & & & & & & & & & & & & & & \\
\hline Purpurocardia leonensis & $\mathrm{R}$ & & $\mathrm{R}$ & & & & & $\mathrm{R}$ & & $\mathrm{R}$ & $\mathrm{R}$ & $\mathrm{R}$ & $\mathrm{R}$ & & $\mathrm{R}$ & $\mathrm{R}$ & & & $\mathrm{R}$ \\
\hline Dosinia meriodionalis & $\mathrm{R}$ & & $\mathrm{R}$ & & & C & & $\mathrm{R}$ & & $\mathrm{R}$ & $\mathrm{R}$ & $\mathrm{R}$ & $\mathrm{R}$ & & $\mathrm{R}$ & $\mathrm{R}$ & & & $\mathrm{R}$ \\
\hline \multicolumn{20}{|l|}{ Dosinia elsai } \\
\hline Pitaria ninfasiensis & & & & & & C & & & & & & & & & & & & & \\
\hline Pitaria trigonus & & & & & & C & & & & & & & & & & & & & \\
\hline Anomalocardia entrerriana & & & & & & $\mathrm{C}$ & & & & & & & & & & & & & \\
\hline Chionopsis australis & & & & & & C & & & & & & & & & & & & & \\
\hline Mactra sp. & & & & & & C & & & & & & & & & & & & & \\
\hline \multicolumn{20}{|l|}{ Dinocardium novus } \\
\hline \multirow{2}{*}{\multicolumn{20}{|c|}{ Cyrtopleura lanceol ata }} \\
\hline Anadara lirata & & & & & & & & & & & & & & & & & & & \\
\hline Trophon laciniatus & $\mathrm{R}$ & & & A & A & C & & $\mathrm{R}$ & & $\mathrm{R}$ & $\mathrm{R}$ & $\mathrm{R}$ & $\mathrm{R}$ & & $\mathrm{R}$ & $\mathrm{R}$ & & & $\mathrm{R}$ \\
\hline Mytilus trigonus & & & & C & C & $\mathrm{R}$ & & & & & & & & & & & & & \\
\hline E pitonium borcherti & & & & C & C & & & & & & & & & & & & & & \\
\hline Calliostoma spp. & & & & C & C & & & & & & & & & & & & & & \\
\hline
\end{tabular}

APPENDIX 1

Continued.

RELATIVE ABUNDANCE OF SPECIES

SHELL-BEDS

$\begin{array}{llllllllllllllllll}\text { E7 } & \text { E8 } & \text { E9 } & \text { F1 } & \text { F2 } & \text { F3 } & \text { F4 } & \text { F5 } & \text { F6 } & \text { F7 } & \text { F8 } & \text { F9 } & \text { F10 } & \text { F11 } & \text { F12 } & \text { F13 F14aF14b F15 }\end{array}$

FOSSIL ASSEMBLAGES

AOA AOA AOA OCAT BOT BOT OCAT GROT OCAT BOT OS AO OS OS BOT OCAT AO OS OS

\begin{tabular}{|c|c|c|c|c|c|c|c|c|c|c|c|c|c|c|c|c|c|c|c|}
\hline $\begin{array}{l}\text { Bryozoans } \\
\text { "Turritela" sp. }\end{array}$ & & & & $\begin{array}{l}\mathrm{R} \\
\mathrm{C}\end{array}$ & $\begin{array}{l}\mathrm{D} \\
\mathrm{A}\end{array}$ & $\begin{array}{l}\mathrm{D} \\
\mathrm{A}\end{array}$ & $\begin{array}{l}\mathrm{R} \\
\mathrm{C}\end{array}$ & & $\begin{array}{l}\mathrm{R} \\
\mathrm{C}\end{array}$ & $\begin{array}{l}\text { D } \\
\text { A }\end{array}$ & & & & & $\begin{array}{l}\text { D } \\
A\end{array}$ & $\begin{array}{l}\mathrm{R} \\
\mathrm{C}\end{array}$ & & & \\
\hline Retrotapes ninfasiensis & & & & & & & & C & & & & & & & & & & & \\
\hline Glycymerita magna & & & & & & & & D & & & & & & & & & & & \\
\hline Ostrea alvarezi & & & & C & $\mathrm{C}$ & $\mathrm{C}$ & C & & C & C & A & & C & $\mathrm{C}$ & $\mathrm{C}$ & C & & & $\mathrm{C}$ \\
\hline Ostrea patagonica & C & C & C & C & $\mathrm{R}$ & $\mathrm{R}$ & C & & C & $\mathrm{R}$ & D & D & D & D & $\mathrm{R}$ & C & D & D & D \\
\hline Chlamys actinodes & & & & D & & & D & & D & & & & & & & $\mathrm{D}$ & & & \\
\hline Aequipecten paranensis & A & A & A & A & & & A & & A & & & & & & & A & & D & \\
\hline Amusium paris & D & D & D & & & & & & & & & D & & & & & $\mathrm{D}$ & & \\
\hline Flabelipecten piramidesensis & & & & & & & & & & & & & & & & & & & \\
\hline Chesapecten crassus & & & & & & & & & & & & & & & & & & & \\
\hline Monophoraster darwini & & & & & & & & & & & & & & & & & & & \\
\hline Ameghinomya argentina & & & & $\mathrm{R}$ & & & $\mathrm{R}$ & & $\mathrm{R}$ & & & & & & $\mathrm{R}$ & & & & \\
\hline Ameghinomya meriodionalis & & & & & & & & & & & & & & & & & & & \\
\hline Pachymagas piramidesia & C & C & C & C & & & $\mathrm{C}$ & & C & & & & & & $\mathrm{C}$ & & & & \\
\hline Panopea regularis & & & & $\mathrm{R}$ & & & $\mathrm{R}$ & & $\mathrm{R}$ & & & & & & & $\mathrm{R}$ & & & \\
\hline Pteromyrtea danieli & & & & & & & & & & & & & & & & & & & \\
\hline Purpurocardia leonensis & & & & $\mathrm{R}$ & & & $\mathrm{R}$ & & $\mathrm{R}$ & & & & & & & $\mathrm{R}$ & & & \\
\hline Dosinia meridionalis & & & & $\mathrm{R}$ & & & $\mathrm{R}$ & & $\mathrm{R}$ & & & & & & & $\mathrm{R}$ & & & \\
\hline Dosinia elsai & & & & & & & & & & & & & & & & & & & \\
\hline Pitaria ninfasiensis & & & & & & & & & & & & & & & & & & & \\
\hline Pitaria trigonus & & & & & & & & & & & & & & & & & & & \\
\hline Anomalocardia entrerriana & & & & & & & & & & & & & & & & & & & \\
\hline Chionopsis australis & & & & & & & & & & & & & & & & & & & \\
\hline Mactra sp. & & & & & & & & & & & & & & & & & & & \\
\hline Dinocardium novus & & & & & & & & & & & & & & & & & & & \\
\hline Cyrtopleura lanceol ata & & & & & & & & & & & & & & & & & & & \\
\hline Anadara lirata & & & & & & & & & & & & & & & & & & & \\
\hline Trophon Iaciniatus & & & & $\mathrm{R}$ & & & $\mathrm{R}$ & & $\mathrm{R}$ & & & & & & & $\mathrm{R}$ & & & \\
\hline $\begin{array}{l}\text { Mytilus trigonus } \\
\text { Epitonium borcherti }\end{array}$ & & & & & & & & & & & & & & & & & & & \\
\hline $\begin{array}{l}\text { Epitonium borcherti } \\
\text { Calliostoma spp. }\end{array}$ & & & & & & & & & & & & & & & & & & & \\
\hline
\end{tabular}


APPENDIX 1

Continued.

\begin{tabular}{|c|c|c|c|c|c|c|c|c|c|c|c|c|c|c|c|c|c|c|c|}
\hline \multirow[b]{2}{*}{ SHELL-BEDS } & \multicolumn{19}{|c|}{ RELATIVE ABUNDANCE OF SPECIES } \\
\hline & F16 & F17 & F18 & F 19 & $\mathrm{~F} 20$ & $\mathrm{~F} 21$ & $\mathrm{~F} 22$ & $\mathrm{~F} 23$ & $\mathrm{~F} 24$ & $\mathrm{~F} 25$ & G1 & $\mathrm{G} 2$ & G3 & G4 & G5 & G6 & G7 & G8 & G9 \\
\hline FOSSIL ASSEMBLAGES & Вот & Вот & вот & OCAT & $\mathrm{AOA}$ & AOA & $\mathrm{AOA}$ & AOA & MO & OMA & OCAT & OCAT & OCAT & GROT & Вот & OCAT & GROT & Вот & OCAT \\
\hline Bryozoans & $\mathrm{D}$ & $\mathrm{D}$ & D & $\mathrm{R}$ & & & & & & & $\mathrm{R}$ & $\mathrm{R}$ & $\mathrm{R}$ & & D & $\mathrm{R}$ & & D & $\mathrm{R}$ \\
\hline $\begin{array}{l}\text { "Turritella" sp. } \\
\text { Retrotapes ninfasiensis }\end{array}$ & A & A & A & c & & & & & & $\mathrm{R}$ & c & c & c & & A & c & & A & c \\
\hline Glycymerita magna & & & & & & & & & & & & & & D & & & D & & \\
\hline Ostrea alvarezi & c & c & c & c & & & & & & & c & c & c & & C & c & & c & c \\
\hline $\begin{array}{l}\text { Ostrea patagonica } \\
\text { Chlamys actinodes }\end{array}$ & $\mathrm{R}$ & $\mathrm{R}$ & $\mathrm{R}$ & $\begin{array}{l}\text { C } \\
\text { D }\end{array}$ & c & c & c & c & D & c & $\begin{array}{l}\text { C } \\
\text { D }\end{array}$ & $\begin{array}{l}\text { C } \\
\text { D }\end{array}$ & $\begin{array}{l}\text { C } \\
\text { D }\end{array}$ & & $\mathrm{R}$ & $\begin{array}{l}\text { C } \\
\text { D }\end{array}$ & & $\mathrm{R}$ & $\begin{array}{l}\text { C } \\
\text { D }\end{array}$ \\
\hline Aequi pecten paranensis & & & & A & A & A & A & A & & A & A & A & A & & & A & & & A \\
\hline $\begin{array}{l}\text { Amusium paris } \\
\text { Flabellipecten piramidesensis } \\
\text { Chesapecten crassus }\end{array}$ & & & & & D & D & D & D & & & & & . & & & & & & 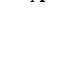 \\
\hline $\begin{array}{l}\text { Cnesapectenc crassus } \\
\text { Monophoraster darwini }\end{array}$ & & & & & & & & & D & A & & & & & & & & & \\
\hline $\begin{array}{l}\text { Ameghinomya argentina } \\
\text { Ameghinomya meriodionalis }\end{array}$ & & & & $\mathrm{R}$ & & & & & & & $\mathrm{R}$ & $\mathrm{R}$ & $\mathrm{R}$ & & & $\mathrm{R}$ & & & $\mathrm{R}$ \\
\hline $\begin{array}{l}\text { Pachymagas piramidesia } \\
\text { Panopea regularis }\end{array}$ & & & & $\begin{array}{l}\mathrm{C} \\
\mathrm{R}\end{array}$ & c & c & c & C & & & $\begin{array}{l}C \\
R\end{array}$ & $\begin{array}{l}\mathrm{C} \\
\mathrm{R}\end{array}$ & $\begin{array}{l}\mathrm{C} \\
\mathrm{R}\end{array}$ & & & $\begin{array}{l}\mathrm{C} \\
\mathrm{R}\end{array}$ & & & $\begin{array}{l}\mathrm{C} \\
\mathrm{R}\end{array}$ \\
\hline $\begin{array}{l}\text { Pteromyrtea danieli } \\
\text { Purpurocardia leonensis }\end{array}$ & & & & $R$ & & & & & & $\mathrm{R}$ & $R$ & R & $R$ & & & R & & & $R$ \\
\hline $\begin{array}{l}\text { Dosinia meridionalis } \\
\text { Dosinia esai } \\
\text { Pitaria ninfasiensis } \\
\text { Pitaria trigonus } \\
\text { Anomalocardia entreriana } \\
\text { Chionopsis australis } \\
\text { Mactra sp. } \\
\text { Dinocardium novus } \\
\text { Cyrtopleura lanceol ata } \\
\text { Anadara lirata }\end{array}$ & & & & $\mathrm{R}$ & & & & & & & $\mathrm{R}$ & $\mathrm{R}$ & $\mathrm{R}$ & & & $\mathrm{R}$ & & & $\mathrm{R}$ \\
\hline $\begin{array}{l}\text { Anadara lirata } \\
\text { Trophon laciniatus } \\
\text { Mytilus trigonus } \\
\text { Epitonium borcherti } \\
\text { Calliostoma spp. }\end{array}$ & & & & $\mathrm{R}$ & & & & & & $\mathrm{R}$ & $\mathrm{R}$ & $\mathrm{R}$ & $\mathrm{R}$ & & & $\mathrm{R}$ & & & $\mathrm{R}$ \\
\hline
\end{tabular}

Continued.

APPENDIX 1

\begin{tabular}{|c|c|c|c|c|c|c|c|c|c|c|c|c|c|c|c|c|c|c|c|}
\hline \multirow[b]{2}{*}{ SHELL-BEDS } & \multicolumn{19}{|c|}{ RELATIVE ABUNDANCE OF SPECIES } \\
\hline & $\mathrm{H} 1$ & $\mathrm{H} 2$ & H3 & $\mathrm{H} 4 \mathrm{a}$ & $\mathrm{H} 4 \mathrm{~b}$ & $\mathrm{H} 4 \mathrm{C}$ & H5 & $\mathrm{H} 6$ & $\mathrm{H} 7$ & H8 & $\mathrm{H} 9$ & $\mathrm{H} 10$ & $\mathrm{H} 11$ & $\mathrm{H} 12$ & $\mathrm{H} 13$ & $\mathrm{H} 14 \mathrm{a}$ & $-14 b$ & $\mathrm{H} 15$ & H16 \\
\hline FOSSIL ASSEMBLAGES & $\mathrm{AOA}$ & os & MO & $\mathrm{AOA}$ & MZ & $v$ & MO & $v$ & NOT & MO & МOT & CAF & GROT & $M Z$ & МOT & MO & MZ & вот & MO \\
\hline Bryozoans & & & & & c & & & & & & & & & c & & & c & D & \\
\hline "Turritella"sp. & & & & & c & & & & $\mathrm{R}$ & & $\mathrm{R}$ & & & c & $\mathrm{R}$ & & c & A & \\
\hline $\begin{array}{l}\text { Retrotapes ninfasiensis } \\
\text { Glycymerita magna }\end{array}$ & & & & & & & & & & & & & $D$ & & & & & & \\
\hline Ostrea alvarezi & & c & & & c & & & & D & & D & c & D & c & D & & c & c & \\
\hline $\begin{array}{l}\text { Ostrea patagonica } \\
\text { Chlamys actinodes }\end{array}$ & c & $\mathrm{D}$ & D & c & c & & $\mathrm{D}$ & & & $\mathrm{D}$ & & c & & c & & $\mathrm{D}$ & C & $\mathrm{R}$ & D \\
\hline $\begin{array}{l}\text { Chlamys actinodes } \\
\text { Aequipecten paranensis }\end{array}$ & A & & & A & C & & & & $\mathrm{R}$ & & $\mathrm{R}$ & A & & c & $\mathrm{R}$ & & C & & \\
\hline $\begin{array}{l}\text { Amusium paris } \\
\text { Flabellipecten piramidesensis }\end{array}$ & D & & & D & & & & & & & & $\begin{array}{l}\text { A } \\
\text { C }\end{array}$ & & & & & & & \\
\hline $\begin{array}{l}\text { Chesapecten crassus } \\
\text { Chas }\end{array}$ & & & & & & & & & & & & $\mathrm{c}$ & & & & & & & \\
\hline $\begin{array}{l}\text { Monophoraster darwini } \\
\text { Ameghinomya argentina }\end{array}$ & & & D & & $\begin{array}{l}\mathrm{C} \\
\mathrm{C}\end{array}$ & C & D & & $\mathrm{R}$ & $\mathrm{D}$ & $\mathrm{R}$ & & & c & $\mathrm{R}$ & D & $\begin{array}{l}\mathrm{C} \\
\mathrm{C}\end{array}$ & & D \\
\hline Ameghinomya meriodionalis & & & & & & c & & c & & & & & & & & & & & \\
\hline $\begin{array}{l}\text { Pachymagas piramidesia } \\
\text { Panopeg reaularis }\end{array}$ & C & & & C & C & & & c & & & & $\begin{array}{r}R \\
R\end{array}$ & & c & & & c & & \\
\hline $\begin{array}{l}\text { Panopea regularis } \\
\text { Pteromyrtea danieli }\end{array}$ & & & & & & & & & & & & $R$ & & & & & & & \\
\hline Purpurocardia leonensis & & & & & & & & & & & & $\mathrm{R}$ & & & & & & & \\
\hline Dosinia meridionalis & & & & & c & c & & c & & & & & & c & & & C & & \\
\hline $\begin{array}{l}\text { Dosinia elsai } \\
\text { Pitaria ninfasiensis }\end{array}$ & & & & & $c$ & C & & C & & & & & & & & & & & \\
\hline $\begin{array}{l}\text { Pitaria ninfasiensis } \\
\text { Pitaria trigonus }\end{array}$ & & & & & c & $\begin{array}{l}\mathrm{C} \\
\mathrm{C}\end{array}$ & & $\begin{array}{l}\mathrm{C} \\
\mathrm{C}\end{array}$ & & & & & & c & & & c & & \\
\hline Anomalocardia entreriana & & & & & C & c & & c & & & & & & C & & & C & & \\
\hline Chionopsis australis & & & & & c & c & & c & & & & & & c & & & C & & \\
\hline Mactra sp. & & & & & c & c & & c & & & & & & c & & & C & & \\
\hline $\begin{array}{l}\text { Dinocardium novus } \\
\text { Cyrtopleura Ianceol ata }\end{array}$ & & & & & & C & & c & & & & & & & & & C & & \\
\hline $\begin{array}{l}\text { Cyrtopleura Ianceol ata } \\
\text { Anadara lirata }\end{array}$ & & & & & $\mathrm{R}$ & $\begin{array}{l}C \\
R\end{array}$ & & $\mathrm{R}$ & & & & & & R & & & $\mathrm{R}$ & & \\
\hline Trophon Iaciniatus & & & & & C & & & & A & & A & & & C & A & & C & & \\
\hline Mytilus trigonus & & & & & $\mathrm{R}$ & & & & c & & c & & & $\mathrm{R}$ & c & & $\mathrm{R}$ & & \\
\hline $\begin{array}{l}\text { Epitonium borcherti } \\
\text { Calliostoma spp. }\end{array}$ & & & & & & & & & $\begin{array}{l}\mathrm{C} \\
\mathrm{c}\end{array}$ & & $\begin{array}{l}\mathrm{C} \\
\mathrm{c}\end{array}$ & & & & $\begin{array}{l}\mathrm{C} \\
\mathrm{c}\end{array}$ & & & & \\
\hline
\end{tabular}


APPENDIX 1

Continued.

\begin{tabular}{|c|c|c|c|c|c|c|c|c|c|c|c|c|c|c|c|c|c|c|c|}
\hline \multirow[b]{2}{*}{ SHELL-BEDS } & \multicolumn{19}{|c|}{ RELATIVE ABUNDANCE OF SPECIES } \\
\hline & $\mathrm{H} 17$ & $\mathrm{H} 18$ & $\mathrm{H} 19$ & 11 & $12 a$ & $12 \mathrm{~b}$ & I2c & 13 & 14 & 15 & 16 & 17 & 18 & 19 & 110 & 111 & 112 & 113 & 114 \\
\hline FOSSIL ASSEMBLAGES & MZ & AOA & МОт & MO & CAF & CAF & CAF & GROT & МОТ & MO & OMA & GROT & МОТ & $\mathrm{v}$ & os & MO & OMA & OMA & OMA \\
\hline $\begin{array}{l}\text { Bryozoans } \\
\text { "Turritella" sn }\end{array}$ & C & & $R$ & & & & & & & & & & & & & & & & \\
\hline $\begin{array}{l}\text { "Turritela" sp. } \\
\text { Retrotapes ninfasiensis }\end{array}$ & C & & $\mathrm{R}$ & & & & & c & $\mathrm{R}$ & & $\mathrm{R}$ & C & $\mathrm{R}$ & & & & $\mathrm{R}$ & $\mathrm{R}$ & $\mathrm{R}$ \\
\hline Glycymerita magna & & & & & & & & D & & & & D & & & & & & & \\
\hline Ostrea alvarezi & C & & D & & c & c & c & & D & & & & D & & A & & & & \\
\hline $\begin{array}{l}\text { Ostrea patagonica } \\
\text { Chlamys actinodes }\end{array}$ & c & c & & D & c & c & c & & & $\mathrm{D}$ & c & & & & D & D & c & c & \\
\hline $\begin{array}{l}\text { Chlamys actinodes } \\
\text { Aequipecten paranensis }\end{array}$ & C & A & R & & $\begin{array}{l}C \\
A\end{array}$ & $\begin{array}{l}C \\
A\end{array}$ & $\begin{array}{l}C \\
A\end{array}$ & & $\mathrm{R}$ & & 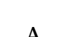 & & R & & & & A & A & A \\
\hline $\begin{array}{l}\text { Aequipecten paranensis } \\
\text { Amusium paris }\end{array}$ & $c$ & $\begin{array}{l}A \\
D\end{array}$ & $\mathrm{R}$ & & $\begin{array}{l}A \\
A\end{array}$ & $\begin{array}{l}\text { A } \\
A\end{array}$ & $\begin{array}{l}A \\
A\end{array}$ & & $\mathrm{R}$ & & A & & $\mathrm{R}$ & & & & A & A & A \\
\hline $\begin{array}{l}\text { Flabellipecten piramidesensis } \\
\text { Chesapecten crassus }\end{array}$ & & & & & $\begin{array}{l}\mathrm{C} \\
\mathrm{C}\end{array}$ & $\begin{array}{l}\mathrm{c} \\
\mathrm{c}\end{array}$ & $\begin{array}{l}\mathrm{C} \\
\mathrm{c}\end{array}$ & & & & & & & & & & & & \\
\hline Monophoraster darwini & c & & $\mathrm{R}$ & D & & & & & $\mathrm{R}$ & $\mathrm{D}$ & A & & $\mathrm{R}$ & & & D & A & A & A \\
\hline & c & & & & & & & & & & & & & & & & & & \\
\hline $\begin{array}{l}\text { Ameghinomya mererodionalis } \\
\text { Pachymagas piramidesia }\end{array}$ & c & c & & & $\mathrm{R}$ & $\mathrm{R}$ & $\mathrm{R}$ & & & & & & & & & & & & \\
\hline Panopea regularis & 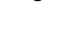 & & & & $\mathrm{R}$ & $\mathrm{R}$ & $\mathrm{R}$ & & & & & & & & & & & & \\
\hline Pteromyrtea danieli & & & & & $\mathrm{R}$ & $\mathrm{R}$ & $\mathrm{R}$ & & & & $\mathrm{R}$ & & & & & & $\mathrm{R}$ & $\mathrm{R}$ & $\mathrm{R}$ \\
\hline Purpurocardia leonensis & & & & & $\mathrm{R}$ & $\mathrm{R}$ & $\mathrm{R}$ & & & & & & & & & & & & \\
\hline Dosinia meridionalis & c & & & & & & & & & & & & & & & & & & \\
\hline $\begin{array}{l}\text { Dosinia edsai } \\
\text { Pitaria ninfasiensis }\end{array}$ & & & & & & & & & & & & & & & & & & & \\
\hline $\begin{array}{l}\text { Pitaria trigonus } \\
\text { Pans }\end{array}$ & c & & & & & & & & & & & & & & & & & & \\
\hline Anomal ocardia entreriana & c & & & & & & & & & & & & & & & & & & \\
\hline Chionopsis australis & c & & & & & & & & & & & & & & & & & & \\
\hline Mactra sp. & C & & & & & & & & & & & & & & & & & & \\
\hline $\begin{array}{l}\text { Dinocardium novus } \\
\text { Cyrtopleura lanceolata }\end{array}$ & c & & & & & & & & & & & & & & $\mathrm{D}$ & & & & \\
\hline $\begin{array}{l}\text { Cyrtopleura lanceol ata } \\
\text { Anadara lirata }\end{array}$ & $\mathrm{R}$ & & & & & & & & & & & & & & 0 & & & & \\
\hline Trophon laciniatus & c & & A & & & & & & A & & $\mathrm{R}$ & & & A & & & $\mathrm{R}$ & $\mathrm{R}$ & $\mathrm{R}$ \\
\hline Mytilus trigonus & $\mathrm{R}$ & & c & & & & & & c & & & & & c & & & & & \\
\hline $\begin{array}{l}\text { Epitonium borcherti } \\
\text { Calliostoma spp. }\end{array}$ & & & $\begin{array}{l}\mathrm{C} \\
\mathrm{C}\end{array}$ & & & & & & $\begin{array}{l}\mathrm{C} \\
\mathrm{C}\end{array}$ & & & & & $\begin{array}{l}\mathrm{C} \\
\mathrm{C}\end{array}$ & & & & & \\
\hline
\end{tabular}

Continued

APPENDIX 1

\begin{tabular}{|c|c|c|c|c|c|c|c|c|c|c|c|c|c|c|c|c|c|c|c|}
\hline \multirow[b]{2}{*}{ SHELL-BEDS } & \multicolumn{19}{|c|}{ RELATIVE ABUNDANCE OF SPECIES } \\
\hline & 115 & J 1 & $\mathrm{~J} 2$ & J 3 & $\mathrm{~J} 4$ & $J 5$ & J 6 & $\mathrm{~J} 7$ & $\mathrm{~J} 8$ & J 9 & $\mathrm{~J} 10$ & $\mathrm{~J} 11$ & $\mathrm{~J} 12$ & $\mathrm{~J} 13$ & $\mathrm{~J} 14$ & $\mathrm{~J} 15$ & $\mathrm{~J} 16$ & $\mathrm{~J} 17$ & $\mathrm{~K} 1$ \\
\hline FOSSIL ASSEMBLAGES & os & MO & CAF & $\mathrm{v}$ & OS & CAF & $\mathrm{AO}$ & Вот & $\mathrm{v}$ & $\mathrm{AO}$ & os & CAF & os & $\mathrm{AO}$ & $\mathrm{AO}$ & os & $\mathrm{AO}$ & MZ & os \\
\hline $\begin{array}{l}\text { Bryozoans } \\
\text { "Turritella" sp. } \\
\text { Retrotapes ninfasiensis }\end{array}$ & & & & & & & & $\begin{array}{l}\mathrm{D} \\
\mathrm{A}\end{array}$ & & & & & & & & & & $\begin{array}{l}\mathrm{C} \\
\mathrm{C}\end{array}$ & \\
\hline \multicolumn{20}{|l|}{$\begin{array}{l}\text { Retrotapes ninfasiensis } \\
\text { Glycymerita magna }\end{array}$} \\
\hline $\begin{array}{l}\text { Ostrea alvarezi } \\
\text { Ostrea patagonica }\end{array}$ & $\begin{array}{l}\text { C } \\
\text { D }\end{array}$ & $\mathrm{D}$ & $\begin{array}{l}c \\
c\end{array}$ & & $\begin{array}{l}\text { C } \\
\text { D }\end{array}$ & $\begin{array}{l}\text { C } \\
c\end{array}$ & $\mathrm{D}$ & $\begin{array}{l}\mathrm{C} \\
\mathrm{R}\end{array}$ & & $\mathrm{D}$ & $\begin{array}{l}\text { C } \\
\text { D }\end{array}$ & $\begin{array}{l}\mathrm{C} \\
\mathrm{C}\end{array}$ & $\begin{array}{l}\text { C } \\
D\end{array}$ & $\mathrm{D}$ & $\mathrm{D}$ & $\begin{array}{l}\text { A } \\
\text { D }\end{array}$ & $D$ & $\begin{array}{l}\mathrm{C} \\
\mathrm{C}\end{array}$ & $\begin{array}{l}\text { C } \\
\text { D }\end{array}$ \\
\hline $\begin{array}{l}\text { Chlamys actinodes } \\
\text { Aequipecten paranensis }\end{array}$ & & & C & & & c & & & & & & c & & & & & & & \\
\hline $\begin{array}{l}\text { Aequipecten paranensis } \\
\text { Amusium paris }\end{array}$ & & & A & & & A & $\mathrm{D}$ & & & $D$ & & A & & $\mathrm{D}$ & $\mathrm{D}$ & & & c & \\
\hline Flabellipecten piramidesensis & & & $\mathrm{c}$ & & & $\mathrm{c}$ & & & & & & $\hat{\mathrm{c}}$ & & & & & D & & \\
\hline Chesapecten crassus & & & C & & & c & & & & & & c & & & & & & & \\
\hline \multirow{2}{*}{\multicolumn{20}{|c|}{$\begin{array}{l}\text { Monophoraster darwini } \\
\text { Ameghinomya argentina } \\
\text { Ameghinomya meriodionalis }\end{array}$}} \\
\hline & & & & & & & & & & & & $\mathrm{R}$ & & & & & & $c$ & \\
\hline Panopea regularis & & & $\mathrm{R}$ & & & $\mathrm{R}$ & & & c & & & $\mathrm{R}$ & & & & & & & \\
\hline Pteromyrtea danieli & & & $\mathrm{R}$ & & & $\mathrm{R}$ & & & & & & $\mathrm{R}$ & & & & & & & \\
\hline Purpurocardia leonensis & & & $\mathrm{R}$ & & & $\mathrm{R}$ & & & & & & $\mathrm{R}$ & & & & & & & \\
\hline $\begin{array}{l}\text { Dosinia meridionalis } \\
\text { Dosinia esai }\end{array}$ & & & & $\mathrm{D}$ & & & & & c & & & & & & & & & C & \\
\hline Pitaria ninfasiensis & & & & & & & & & $\mathrm{c}$ & & & & & & & & & c & \\
\hline Pitaria trigonus & & & & & & & & & C & & & & & & & & & c & \\
\hline Anomalocardia entrerriana & & & & & & & & & C & & & & & & & & & c & \\
\hline Chionopsis australis & & & & & & & & & C & & & & & & & & & c & \\
\hline Mactra sp. & & & & & & & & & c & & & & & & & & & c & \\
\hline \multicolumn{20}{|l|}{ Dinocardium novus } \\
\hline $\begin{array}{l}\text { Cyrtopleura lanceol ata } \\
\text { Anadara lirata }\end{array}$ & & & & & & & & & C & & & & & & & & & $\mathrm{R}$ & \\
\hline Trophon laciniatus & & & & & & & & & & & & & & & & & & c & \\
\hline Mytilus trigonus & & & & & & & & & & & & & & & & & & $\mathrm{R}$ & \\
\hline $\begin{array}{l}\text { Epitonium borcherti } \\
\text { Call iostoma spp. }\end{array}$ & & & & & & & & & & & & & & & & & & & \\
\hline
\end{tabular}


APPENDIX 1

Continued.

\begin{tabular}{|c|c|c|c|c|c|c|c|c|c|c|c|c|c|c|}
\hline \multirow[b]{2}{*}{ SHELL-BEDS } & \multicolumn{14}{|c|}{ RELATIVE ABUNDANCE OF SPECIES } \\
\hline & $\mathrm{K} 2$ & K3a & $\mathrm{K} 3 \mathrm{~b}$ & K4 & $\mathrm{K} 5$ & K6 & K7 & $\mathrm{K} 8$ & K9 & K10 & K11 & K12 & $\mathrm{K} 13$ & $\bar{K} 14$ \\
\hline FOSSIL ASSEMBLAGES & os & AO & MO & мо & CAF & $\mathrm{AO}$ & os & os & $\mathrm{AO}$ & os & CAF & CAF & GROT & MZ \\
\hline $\begin{array}{l}\text { Bryozoans } \\
\text { "Turritella" sp. } \\
\text { Retrotapes ninfasiensis } \\
\text { Glycymerita magna } \\
\text { Ostrea alvarezi } \\
\text { Ostrea patagonica } \\
\text { Chlamys actinodes } \\
\text { Aequipecten paranensis } \\
\text { Amusium paris } \\
\text { Flabellipecten piramidesensis } \\
\text { Chesapecten crasssus } \\
\text { Monophoraster darwini } \\
\text { Ameghinomya argentina } \\
\text { Ameghinomya meiodionalis } \\
\text { Pachymagas piramidesia } \\
\text { Panopea regularis } \\
\text { Pteromyrtea daniel } \\
\text { Purpurocardia leonensis } \\
\text { Dosinia meridionalis } \\
\text { Dosinia esai } \\
\text { Pitaria ninfasiensis } \\
\text { Pitaria trigonus } \\
\text { Anomalocardia entreriana } \\
\text { Chionopsis australis } \\
\text { Mactra sp. } \\
\text { Dinocardium novus } \\
\text { Cyrtopleura lanceolata } \\
\text { Anadara lirata } \\
\text { Trophon laciniatus } \\
\text { Mytilus trigonus } \\
\text { Epitonium borcherti } \\
\text { Calliostoma spp. }\end{array}$ & $\begin{array}{l}\text { C } \\
\text { D }\end{array}$ & D & D & $\mathrm{D}$ & $\begin{array}{l}C \\
C \\
C \\
C \\
A \\
A \\
C \\
C \\
C \\
\\
R \\
R \\
R \\
R \\
R\end{array}$ & $\begin{array}{l}\mathrm{D} \\
\mathrm{D}\end{array}$ & $\begin{array}{l}\text { C } \\
\text { D }\end{array}$ & $\begin{array}{l}\text { C } \\
\text { D }\end{array}$ & $\begin{array}{l}\mathrm{D} \\
\mathrm{D}\end{array}$ & $\begin{array}{l}\text { A } \\
\text { D }\end{array}$ & $\begin{array}{l}C \\
C \\
C \\
A \\
A \\
C \\
C\end{array}$ & $\begin{array}{l}\text { C } \\
C \\
C \\
\text { C } \\
A \\
C \\
C\end{array}$ & $\begin{array}{l}\text { A } \\
\text { D }\end{array}$ & $\begin{array}{l}\mathrm{C} \\
\mathrm{C} \\
\mathrm{C} \\
\mathrm{C} \\
\mathrm{C} \\
\mathrm{C} \\
\mathrm{R} \\
\mathrm{C} \\
\mathrm{R}\end{array}$ \\
\hline
\end{tabular}

